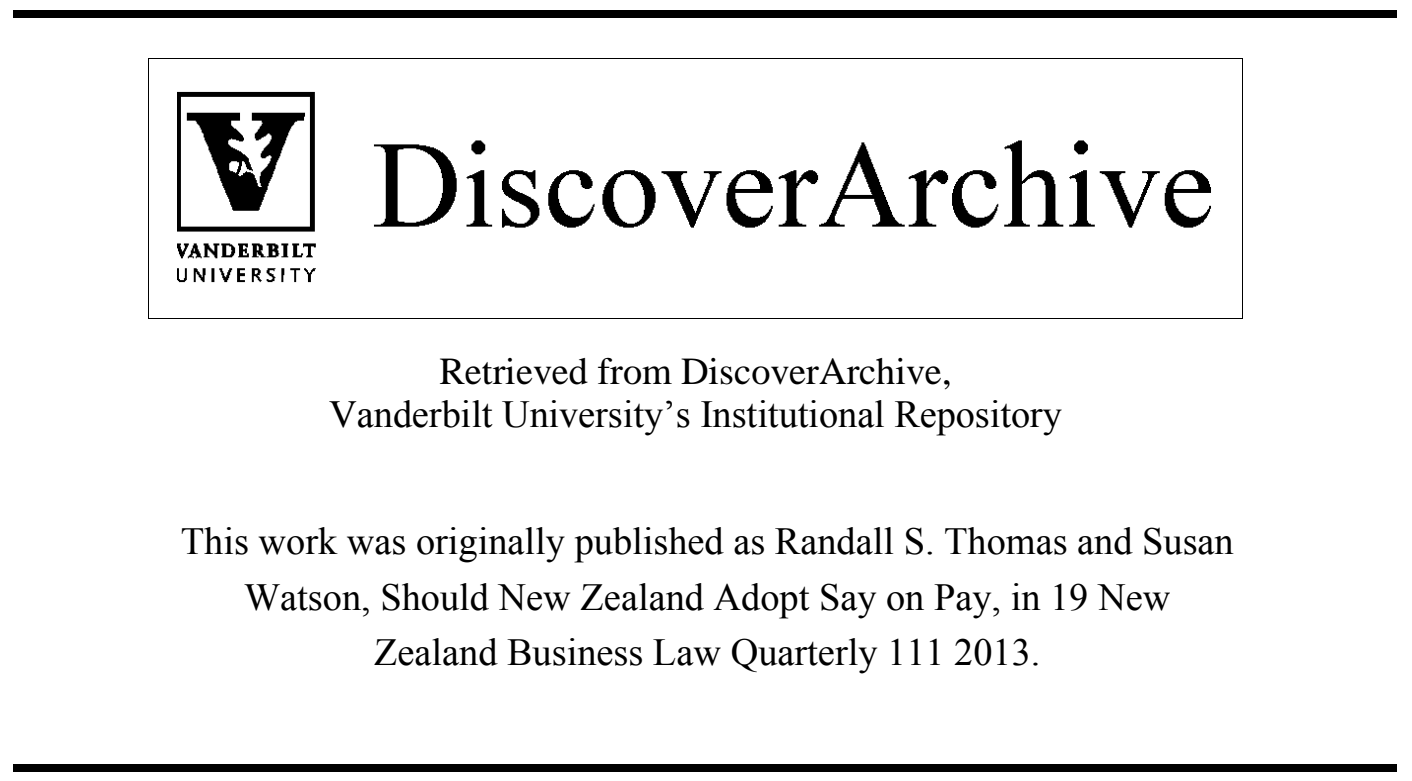




\title{
Should New Zealand Adopt Say on Pay?
}

\author{
RANDALL S. THOMAS* and SUSAN WATSON** \\ * John S. Beasley II Chair in Law and Business, Vanderbilt Law School, Vanderbilt University \\ ** Professor of Law, University of Auckland.
}

\section{INTRODUCTION}

Around the globe, the latest fashion in corporate governance circles is "Say on Pay," a shareholder vote -- sometimes precatory, other times mandatory - on CEO remuneration. Country after country has adopted Say on Pay in response to shareholder disgust over the size of CEO pay packets. Beginning with the U.K., and later followed by the Netherlands, Australia, Sweden, Norway, Belgium, France, Switzerland, and the U.S., there has been a widespread acceptance of the shareholder vote on executive pay around the world. In this article, we ask the question: Should New Zealand follow the crowd and adopt Say on Pay, or should it continue down its own path, leaving directors with near total control over executive remuneration levels?

Academics are divided over the desirability of Say on Pay -- those that believe in strong managerial power are firmly against it, while shareholder activists come out heavily in its favor. The main theoretical arguments revolve around whether: it will tip the balance of power against managers; shareholders are competent to evaluate executive remuneration; third party voting advisors will gain too much power if it is enacted; there will be any reduction in the size, and rate of growth, of CEO pay packets; and it will strengthen the relationship between pay and performance.

The experience in the U.K. and the U.S. to date sheds some light on the validity of these arguments. On average, shareholders have voted strongly in favor of executive pay practices at most companies. Say on Pay seems to have had little impact on the size and growth of average CEO pay, but it does appear to have impacted pay practices at poorly performing companies that have unusually high pay. There is a greater level of engagement between shareholders and managers on pay issues at many companies, and firms have become more responsive to negative shareholder Say on Pay votes. Third party voting advisors, such as Institutional Shareholder Services, have become important corporate governance players, whose recommendations have a significant impact on shareholder voting outcomes.

In light of these academic arguments, and practical experience in the U.K. and U.S., we believe that New Zealand should carefully consider whether to adopt Say on Pay. We do not view the evidence as compelling the conclusion that Say on Pay is essential, but we can understand why some shareholders might want to see it implemented. However, the existing evidence shows that it is unlikely to have a big effect on current pay practices at most companies in New Zealand if it is adopted. 
This article proceeds as follows. In Section I, we lay out the legal and corporate governance framework for setting executive remuneration in New Zealand. We move on in section II to consider the academic arguments for and against the adoption of Say on Pay. In Section III, we summarize the U.K. and American experience with Say on Pay. Finally, in section IV, we summarize the lessons from the earlier sections to consider whether New Zealand should adopt this regime, and if so, how it would do so.

\section{Executive Compensation and Corporate Governance in New Zealand}

An essential first step to our analysis of Say on Pay is to lay a solid foundation for understanding the current system for determining executive remuneration in New Zealand. In this section, we begin by reviewing the legal rules that relate to determining managerial pay. We then look at the basic components of executive remuneration today and the trends in overall levels and composition of managerial pay packets. We finish this section by surveying investor and public reactions in New Zealand to executive remuneration trends.

\section{A. The Legal Rules on Director Compensation In New Zealand}

The legal underpinnings for executive remuneration in New Zealand have developed over time. Under common law, a quantum meruit claim by a director to be paid remuneration was rejected in Wellington Audio Visual Ltd v Euro Boston Group Ltd (No 2). ${ }^{1}$ Heath J rejected the argument that a director could recover reasonable costs of services because directors are fiduciaries. "The risk of conflict, inherent in the benefit for directors who receive remuneration and (potential) detriment to the company that pays, has led to prescriptive rules being adopted to promote informed decision-making about whether (and to what extent) a director should be remunerated." Since no automatic right to remuneration for agreeing to act as a director of a company exists at common law, ${ }^{3}$ and directors are not automatically employees of the company by virtue of having been appointed, executive directors must enter into a separate employment arrangement with the company. ${ }^{4}$ Executive directors are then entitled both to directors' fees and to remuneration as employees.

Both executive and non-executive directors must comply with the remuneration provision of the Companies Act 1993; s 161. Subject to any restriction in the constitution, the board has the authority to authorize payment of remuneration or other benefits to directors for services performed as a director or in any other capacity. This provision includes employment agreements. ${ }^{5}$ Payment made pursuant to employment agreements authorized under the provision

\footnotetext{
${ }^{1}$ Wellington Audio Visual Ltd v Euro Boston Group Ltd (No 2) 31/3/10, Heath J, HC Auckland CIV-2007-4041089.

${ }^{2}$ Ibid, para 23. The Judge followed Guinness Plc v Saunders [1990] 2 AC 663, where the House of Lords said that there can be no contract to pay special remuneration for the services of a director unless that contract is entered into pursuant to the articles of association. The New Zealand equivalent is s 161 of the Companies Act 1993.

${ }^{3}$ Guinness Plc v Saunders [1990] 2 AC 663 (HL).

${ }^{4}$ McLenaghan v Kiwi Seed Co Ltd (1993) 4 NZELC 98,182.

${ }^{5}$ Companies Act 1993, s 161(1) (a).
} 
need not be authorized separately. ${ }^{6}$ Perhaps surprisingly, directors are permitted to vote in favor of proposals relating to their own remuneration. ${ }^{7}$ Section 161(1) is expressed to be subject to the constitution of the company so companies in their constitutions can impose additional requirements for remuneration, including requiring that remuneration committees of independent directors be established or requiring that directors not vote on their own remuneration.

The board must be satisfied the remuneration is fair to the company. ${ }^{8}$ The term "fair" is not defined in the legislation nor has there been much litigation on the meaning of the term in a remuneration context. In Managh v Jordan, ${ }^{9}$ the High Court considered whether payments made to the director of a car dealership in the period that he wound up the business were fair in terms of s 161(5). The payments had not been authorized in accordance with s 161. Miller J considered that the payments were fair; the director behaved as a receiver would have in winding up the business. ${ }^{10}$ In Bridgecorp Management Services Ltd (in rec) v Roest, one of the executive directors of Bridgecorp Management Services Ltd (in rec) was ordered to repay \$313,906 of his $\$ 543,000$ salary package. The remuneration and bonus had not been properly approved by the board and exceeded a fair remuneration package. ${ }^{11}$

Determination of fees of for non-executive directors has generally been regarded as a matter for the company with the courts being reluctant to interfere. ${ }^{12}$ However, under the Companies Act 1993, particulars of the payment must be entered in the interests register ${ }^{13}$ and directors voting in favor of the remuneration must state why they consider it is fair to the company. ${ }^{14}$ Excessive remuneration may be evidence of oppression and thus provide for potential remedies for shareholders under s 174 of the Act. Excessive remuneration may also be evidence of an attempt to defraud creditors. ${ }^{15}$

\section{Special Rules for SMEs}

New Zealand has a high number of small and medium enterprises (SMEs); around $97 \%$ of New Zealand's companies are SMEs. An alternative remuneration procedure exists for small or closely held companies. Section 107(1)(f) provides that subject to satisfying the solvency test set out in s 108 of this Act, if all entitled persons have agreed or concur, remuneration may be

${ }^{6}$ Companies Act 1993, s 161(3).

7 Company, Corporate \& Securities Law, NZ Company Law and Practice Commentary, DIRECTORS' RELATIONS WITH COMPANY AND THIRD PARTIES [910-645] Remuneration.

${ }^{8}$ Companies Act 1993, s 161(1).

${ }^{9}$ Managh v Jordan [2010] NZCCLR 4.

${ }^{10}$ Ibid, para 41.

${ }^{11}$ Bridgecorp Management Services Ltd (in rec) v Roest HC Auckland CIV-2008-404-003013, 14 September 2009.

${ }^{12}$ Re Halt Garage (1964) Ltd [1982] 3 All ER 1016.

${ }^{13}$ Companies Act 1993, s 161(2).

${ }^{14}$ Companies Act 1993, s 161(4).

${ }^{15}$ Re Day-Nite Carriers Ltd (in liq) [1975] 1 NZLR 172. 
authorized otherwise than in accordance with s 161(1). Entitled persons are shareholders and persons upon whom the constitution confers any of the rights and powers of a shareholder. ${ }^{16}$ Section 107(4) provides that even if all entitled persons agree: "no agreement or concurrence of the entitled persons is valid or enforceable unless the agreement or concurrence is in writing." In National Trade Manuals Ltd (in liq) $v$ Watson, ${ }^{17}$ the court considered that the effect of a failure to comply with this provision invalidated the payment. ${ }^{18}$ If there is no proper explanation for the drawings or a valid resolution classifying the drawings in some other way, such as distributions or salary, such drawings remained as advances repayable on demand. ${ }^{19}$

New Zealand has a relatively small proportion of companies with dispersed ownership. According to Berle, companies where ownership is so widely distributed that no one individual or group has a minority interest that is large enough to allow them to exert dominance over the company's affairs should be classified as management control companies. ${ }^{20}$ A study of the New Zealand Stock Exchange (NZX) top fifty companies in 2009 showed that only $24 \%$ had management control. ${ }^{21}$ Most (38\%) had minority control. Say on Pay legislation would be likely to have the biggest impact on companies that are management controlled as it is in those companies that shareholders currently have the least power to affect compensation.

\section{Golden Handshakes}

"Golden handshake" payments are payments made to directors for loss of office. The payments are made either as damages for breach of a separate employment agreement or for loss of office as director. Whereas the distinction was important under the earlier Companies Act $1955,{ }^{22}$ the procedure for both types of payments to directors is the same under the Companies Act 1993. Under the provisions of the Companies Act 1993, which apply to all companies, entering into an agreement to pay an employee director compensation for loss of office is covered by the legislation. ${ }^{23}$ Therefore, when approving employment agreements with substantial golden handshake clauses inserted for executive directors, all directors would have to be satisfied it was fair to the company that such sums be provided. ${ }^{24}$

\footnotetext{
${ }^{16}$ Companies Act 1993, s 2(1).

${ }^{17}$ National Trade Manuals Ltd (in liq) v Watson (2006) 9 NZCLC 264,163 (HC).

${ }^{18}$ Ibid at para 42

${ }^{19}$ National Trade Manuals Ltd (in liq) v Watson (2006) 9 NZCLC 264,163; Re Samarang Developments Ltd (in liq); alt cit Walker v Campbell 30/9/04, John Hansen J, HC Christchurch CIV-2003-409-2094, para 55.

${ }^{20}$ A A Berle and G C Means, The Modern Corporation and Private Property (Harcourt, Brace and World, Inc,1933)

${ }^{21}$ C Giles and S Watson, "Evidence of Ownership and Control in the Top NZX non-financial corporations" (2012) 33 The Company Lawyer 115-128.

${ }^{22}$ Rowe v Taupo Totara Timber Co Ltd [1976] 2 NZLR 506.

${ }^{23}$ Companies Act 1993, subss 161(1) (b), 161(1) (e).

${ }^{24}$ However, it is unlikely, because of s 161 and the directors' statutory duty to exercise powers for a proper purpose, Companies Act 1993, s 133, that entering into such an agreement to repel potential takeovers would be valid.
} 


\section{Disclosure Requirements}

Compared with other jurisdictions, New Zealand has very minimal remuneration disclosure requirements for directors. Section 211(1) (f) merely requires the total of the remuneration and the value of other benefits received by each of the directors or former directors during the accounting period to be disclosed. ${ }^{25}$ But section 211(1) (g) imposes a disclosure requirement for the remuneration of employees. The company in its annual report must state the number of employees or former employees of the company, not being directors of the company, who, during the accounting period, received remuneration and any other benefits in their capacity as employees, the value of which was or exceeded $\$ 100,000$ per annum. The report must state the number of such employees or former employees in brackets of $\$ 10,000{ }^{26}$

The requirement that executive compensation be disclosed has attracted criticism from the New Zealand Securities Commission, the New Zealand Employers Federation, the New Zealand Business Roundtable, the New Zealand Privacy Commissioner and high-profile commercial lawyers. ${ }^{27}$ In 1997 the Privacy Commissioner investigated whether the disclosure of executive compensation was an undue intrusion on the privacy of executives, concluding that it was. The Commissioner concluded that while "directors must be accountable to shareholders [...] employees are usually seen in a somewhat different light, owing their accountability to the chief executive and directors, not the shareholders direct." ${ }^{28}$

While the provision has remained in place, its effectiveness has been questioned. ${ }^{29}$ In fact there is evidence that the introduction of disclosure requirements led to an increase in the level of remuneration of both CEOs and executives. ${ }^{30}$ In a 2002 study of 102 companies listed on the NZX examining executive compensation in the year after disclosure was introduced, there was no evidence found of a relationship between pay and performance. Instead, CEO pay seemed to

\footnotetext{
${ }^{25}$ Compare the requirements in Australia under the Corporations Act 2001 (Cth) s 298, where a directors' report has to be prepared that contains details of board policy regarding remuneration and the relationship between pay and performance. See the discussion in A. Schoenemann, "Executive Remuneration in New Zealand and Australia: Do Current Laws, Regulations and Guidelines Ensure "Pay for Performance?" (2006) 37 VUWLR 31, at pp.63-64.

${ }^{26}$ Companies Act 1993, s 211(1) (f).

${ }^{27}$ A. Andjelkovic, G. Boyle, and W. McNoe, "Public disclosure of executive compensation: Do shareholders need to know?" (2002) 10 Pacific-Basin Finance Journal. 97, 101. See also F Elayan, J Lau, and T Meyer, " Executive Incentive Compensation Schemes and Their Impact on Corporate Performance: Evidence from New Zealand Since

Legal Disclosure Requirements became Effective," (2003) 21 Studies in Economics and Finance 54, (study of 73 listed companies) and Gunasekaragea and Wilkinson, (2002) 10 International Journal of Business Studies 45,( studies which support these findings in the New Zealand context.)

${ }^{28}$ Mandatory Disclosure Of Executive Remuneration Report By The Privacy Commissioner To The Minister Of Justice On The Mandatory Disclosure Of Executive Remuneration Under Section 211 Of The Companies Act 1993, 24 November 1997.

${ }^{29}$ G. Shirtcliffe, "Executive remuneration - does sunlight disinfect or fertilize?" New Zealand Herald, 2 September 2011. ("some sort of "moral licensing" phenomenon can arise - the discloser unconsciously treating the disclosure as having partially discharged their obligations to the beneficiary, thereby making them less assiduous in protecting the beneficiary's interests.")

${ }^{30}$ H. Roberts, "CEO Power, Executive Compensation and Firm Performance New Zealand 1997 - 2002" last updated 15 April 2005 and accessed from http://otago.ourarchive.ac.nz/handle/10523/1524.
} 
depend on firm size. Interestingly though firms that voluntarily disclosed CEO compensation earlier than required did exhibit a positive relationship between pay and performance. ${ }^{31}$

\section{Listed Company Requirements}

Additional requirements exist for companies listed on the New Zealand Stock Exchange (NZX). The aggregated component of directors' remuneration (" a monetary sum per annum payable to all Directors of the Issuer taken together") ${ }^{32}$ payable to directors in that capacity (as opposed to their capacity as executive directors) must be approved by an ordinary resolution of shareholders. The resolution may allow for a part or the whole of the remuneration to be payable by means of equity securities (which is defined broadly to include share options and other forms of securities). ${ }^{33}$ The Rule does not apply to executive remuneration or payment to directors in their capacity as executives; it explicitly states that remuneration for work not in the capacity as director may be approved by the directors without shareholder approval. ${ }^{34}$

The requirements in the Rules are elaborated on in the NZX Corporate Governance Best Practice Code ("the Code'). The Code is non-mandatory, being intended "to enhance investor confidence through corporate governance and accountability" and being "composed of flexible principles which recognise differences in corporate size and culture." Companies are required to disclose the extent to which their corporate governance practices differ from the Code in their annual reports. 35

The Code states that companies, unless constrained by size, should establish remuneration committees and have a formal and transparent method to recommend director's remuneration to shareholders. The annual report should identify the members of the remuneration committee. The Code also recommends that the remuneration committee produce a written charter that outlines its authority, duties, responsibilities and relationship with the board. The charter should also set out any requirements for the composition of the remuneration committee and gives, as an example, that there might be a requirement for a minimum number of independent directors- the Code does not however explicitly recommend that a remuneration committee be comprised, in whole or in part, of independent directors. No details about the composition of director' remuneration are in the Code apart from a recommendation that any equity security plans should not vest for at least two years after the grant of plan entitlements to the director.

\section{Remuneration Committees}

\footnotetext{
${ }^{31}$ A. Andjelkovic, G. Boyle, W. McNoe, "Public disclosure of executive compensation: Do shareholders need to know?” (2002) 10 Pacific-Basin Finance Journal 97.

${ }^{32}$ NZX Limited, NZSX/NZDX Listing Rules (6 August 2010) r 3.5.1.

${ }^{33}$ NZX Limited, NZSX/NZDX Listing Rules (6 August 2010) r 3.5.1, r 1.6.1.

${ }^{34}$ NZX Limited, NZSX/NZDX Listing Rules (6 August 2010) r 3.5.1.

${ }^{35}$ NZX Limited, NZSX/NZDX Listing Rules (6 August 2010), Appendix 16, Corporate Governance Best Practice Code, Foreword.
} 
A study that focused on the impact of the Code found that in 2010, $79.3 \%$ of New Zealand boards had remuneration committees (compared with $33.3 \%$ in 1995.) ${ }^{36}$ This is lower than comparable jurisdictions: (an Australian study found that in 2002, $88 \%$ of Australian listed companies had remuneration committees and a US study found that in the US $99 \%$ had a separate remuneration committee in 2003.) The percentage of independent directors on the New Zealand remuneration committees remained about the same.

Unlike comparable jurisdictions, direct CEO involvement in remuneration determination as members of the remuneration committee is not unusual in New Zealand. A recent study revealed that $21 \%$ of CEOs of surveyed companies were involved as members of the remuneration committee in 2010; a reduction from $35 \%$ in 2000 and $42 \%$ in $1995 .{ }^{37}$

Interestingly, and contrary to the results that might be expected from a managerial power view of executive compensation, a recent study shows that annual pay increments for CEOs with this apparent advantage averaged four percentage points less than those awarded to other CEOs. ${ }^{38}$ The authors conclude that the "results suggest that highly visible arrangements which, on the surface, appear an open invitation for CEOs to behave opportunistically, may in fact induce them to exercise greater restraint."

\section{Regulatory Agencies}

Prior to the global financial crisis, the New Zealand Securities Commission (NZSC) had oversight over the capital markets in New Zealand. It was viewed, depending on the perspective of the commentator, either as insufficiently proactive, or under resourced and lacking power. Following the crisis and the collapse in New Zealand of the finance company sector where nonbank deposit takers were largely unregulated, a more powerful and better resourced body, the Financial Markets Authority (FMA), was created and the functions of the Securities Commission subsumed into the new body. One of the roles of the NZSC taken over by the FMA is an oversight over corporate governance (it oversees securities, financial reporting, and company law as they apply to financial services and securities markets. $)^{39}$ So far, the FMA has adopted corporate governance guidelines from the Securities Commission that were written in 2004. In its Corporate Governance Guidelines, the Financial Markets Authority requires that the remuneration of directors and executives should be transparent, fair, and reasonable, with executive (including executive director) remuneration being clearly differentiated from nonexecutive director remuneration. Executive director remuneration packages should include an element that is dependent on entity and individual performance.

\footnotetext{
${ }^{36}$ G. Boyle and X. Jane, "New Zealand Corporate Boards in Transition: Composition, Activity and Incentives Between 1995 and 2010," last updated on 30 April 2012 and last accessed from: http://papers.ssrn.com/sol3/papers.cfm?abstract_id=2079314 on 2 November 2012, 13.

${ }^{37}$ Ibid at $\mathrm{p} 16$.

${ }^{38}$ G. Boyle and H. Roberts, "CEO Presence on the Compensation Committee: A Puzzle," forthcoming (2012) Journal of Economics and Business last accessed from http://ir.canterbury.ac.nz/handle/10092/5370 on 30 October 2012.

${ }^{39}$ http://www.fma.govt.nz/about-us/ last accessed 25 October 2012.
} 
As one of its last tasks before been disbanded, the New Zealand Securities Commission reviewed corporate governance disclosure by selected issuers against the guidelines. ${ }^{40}$ It found that generally issuers provided clear and comprehensive information on directors' and executives' remuneration, including use of remuneration policies and committees. The NZSC commented that the level of remuneration disclosure has improved significantly since its last review in 2005 with the NZSC recognising that improvements in disclosures may be a result of the increased scrutiny and sensitivity of directors' and executives' remuneration. Roughly $65 \%$ of all issuers disclosed relevant details relating to their remuneration policy for directors and executives compared with $40 \%$ in 2005 ; with $34 \%$ of publicly owned entities publishing that document in full (compared with $25 \%$ in 2005); and $64 \%$ of publicly owned entities disclosed they had a remuneration committee. ${ }^{41}$

The NZSC emphasized the importance of the relationship between remuneration and risk being seen in corporate governance policies, practices and disclosures. In its view, and citing the UK corporate governance code, ${ }^{42}$ remuneration incentives should align with financial and nonfinancial performance measures relating to the issuer's objectives, and be compatible with risk management policies and systems. ${ }^{43}$

In a working paper using semi-structured interviews and examining New Zealand's discourse on executive remuneration, and how it influences remuneration committees' decision making, Neil Crombie found that, while non-executive directors use many rationales to justify or legitimise their decisions, it was the market rationale that dominated the discourse on executive remuneration in New Zealand. ${ }^{44}$

\section{B. Pay Trends for CEOs in New Zealand}

The mix of executive remuneration in New Zealand is broadly consistent with comparable jurisdictions. Remuneration consultants take account of overseas trends in executive compensation. In line with other jurisdictions, this has led to an increase in the levels of remuneration over the past twenty years although the size of the economy, the size of listed companies and the generally sluggish share market has meant both the rate and amount of increase has not been as great as in comparable jurisdictions.

\footnotetext{
${ }^{40}$ New Zealand Securities Commission, Review of Corporate Governance Disclosure by Selected Issuers, July 2010 at http://www.fma.govt.nz/media/178304/cgrp-report.pdf last accessed 25 October 2012.

${ }^{41}$ Ibid at $\mathrm{p} 14$.

${ }^{42}$ Financial Reporting Council Limited, 2010, June. The UK Corporate Governance Code. Available

URL: http://www.frc.org.uk/corporate/ukcgcode.cfm. In New Zealand, Securities Commission, Review of Corporate Governance Disclosure by Selected Issuers, July 2010 at http://www.fma.govt.nz/media/178304/cgrpreport.pdf accessed 25 October 2012, at p15.

${ }^{43}$ New Zealand Securities Commission, Review of Corporate Governance Disclosure by Selected Issuers, July 2010 at http://www.fma.govt.nz/media/178304/cgrp-report.pdf last accessed 25 October 2012, at p15.

44 N.Crombie, "New Zealand's Discourse on Executive Remuneration" last accessed from http://ir.canterbury.ac.nz/handle/10092/4986 on 1 November 2012.
} 
Performance pay is prevalent although this was not the case as late as 2005 where only $75 \%$ of CEOs of listed companies were identified as having a performance-related component in their remuneration. ${ }^{45}$ In 2000 no companies were identified as offering long term incentive (LTI) schemes to their executives ${ }^{46}$ and in 2005 only twelve percent of listed company executives were taking part in a share ownership scheme of any sort. ${ }^{47}$

Perhaps the best recent source of information about executive, executive director and director remuneration trends is the annual PwC Executive Reward Report, which has been produced since $2010{ }^{48}$ The 2012 report includes data from 131 companies, more than 1,000 positions and covers CEO positions and executive roles that report directly to the CEO as well as executive roles that are not CEO direct reports. The participating companies are mainly private sector businesses, but include some state-owned enterprises (SOEs). Two thirds of participating companies have revenue of more than $\$ 100$ million. The report data includes fixed pay, short term incentives (actual, target and deferred) and annualised long term incentive grant values. During the period (year ending 31 March 2012) fixed annual remuneration (FAR) increased by $3.7 \%$ with CEO FAR increasing by $5.8 \%$. About $15 \%$ of executives received no increase. There was an increase in short term incentive (STI) payouts in the period (from $64 \%$ in 2011 to $77 \%$ in 2012) with STI schemes less prevalent in SMEs. In 2011 one- third of those incumbent in positions received total remuneration that was equal to or less than their 2010 packages. In the 2012 survey only seven percent of incumbents were paid the same or less. Overall, approximately $80 \%$ of packages were fixed pay, $15 \%$ were STI payouts, four percent were long term incentive (LTI) grants and one percent were deferred STIs and Kiwisaver. These figures were almost exactly the same as the 2011 figures.

The report identified two clear trends in LTIs. First, most LTI plans designed in New Zealand include performance measures. Secondly, nil price schemes, where executives may receive an equity interest at no cost to themselves, remain prevalent. ${ }^{49}$ In 2012 the number of organization offering LTIs dropped from $45 \%$ in 2011 to $37 \%$ in 2012 but a number of companies indicated that they were in the process of establishing an LTI scheme.

In terms of the relationship with the average wage, the New Zealand experience has mirrored overseas trends. In the Higbee Schäffler 2008 Corporate Services \& Executive Management Survey, the median fixed remuneration for top tier CEOs was $\$ 690,000$, with an

\footnotetext{
${ }^{45}$ Sheffield CEO Survey 2005 (Sheffield, Auckland, 2005) cited in A. Schoenemann, "Executive Remuneration in New Zealand and Australia: Do Current Laws, Regulations and Guidelines Ensure "Pay for Performance?" (2006) 37 VUWLR 31, at p 42.

${ }^{46}$ J. Healy, Corporate Governance and Wealth Creation in New Zealand (Dunmore Press, Palmerston North, 2003) 174.

${ }^{47}$ Sheffield CEO Survey 2005 (Sheffield, Auckland, 2005) cited in A. Schoenemann, "Executive Remuneration in New Zealand and Australia: Do Current Laws, Regulations and Guidelines Ensure "Pay for Performance"?" (2006) 37 VUWLR 31, 44.

${ }^{48}$ PWC, 2012 Executive Reward Report Summary of Findings, October 2012.

${ }^{49}$ Examples of these schemes are performance share rights, share loan and bonus schemes.
} 
additional $\$ 250,000$ in STIs. At that time the average wage was just over $\$ 49,000$, meaning group CEOs in New Zealand earned 14 times in fixed pay what the average employee earned. This contrasts with 1998, when the average wage was just on $\$ 33,300$ and the median pay for a CEO was between 6.5 and 11 times that (about $\$ 215,000$ and $\$ 356,000$ for medium and large companies - with STIs not really featuring). ${ }^{50}$

In terms of quantum, the New Zealand Institute of Directors 2012 survey, which covers 1,610 directorships and 994 organizations throughout New Zealand, found that median fee for a non-executive director increased by $2.9 \%$ to $\$ 36,000$, while the median fee for a non-executive chairman increased by $15.3 \%$ to $\$ 48,834$ over the previous year. ${ }^{51} \mathrm{New}$ Zealand directors are paid about a third less than their Australian counterparts, after adjustments for size and risk. ${ }^{52}$ Senior executive pay rose $84 \%$ in the decade to 2011 , to a median of $\$ 670,000$ in private-sector organizations with a turnover of around $\$ 350$ million a year and with over 1000 employees. Total remuneration rose $60 \%$ to about $\$ 500,000$ in private companies with a turnover of around $\$ 100$ million. ${ }^{53}$ The lower quantum of remuneration in New Zealand than in comparable jurisdictions is not surprising given the smaller average size of New Zealand firms. ${ }^{54}$

A recent study of New Zealand boards in the period between 1995 and 2010, which focused on the impact of the introduction of the NZX corporate governance best practice code, revealed that fees paid to board chairs and directors increased by more than $60 \%$ in real terms during the period (where the all-sector Labor cost index increase over the same period was $1.5 \%$.) Interestingly (and surprisingly given the NZX Best Practice Code recommendation) ownership of shares by directors reduced during the period. ${ }^{55}$

\section{Public and Investor Reaction to Executive Remuneration Trends}

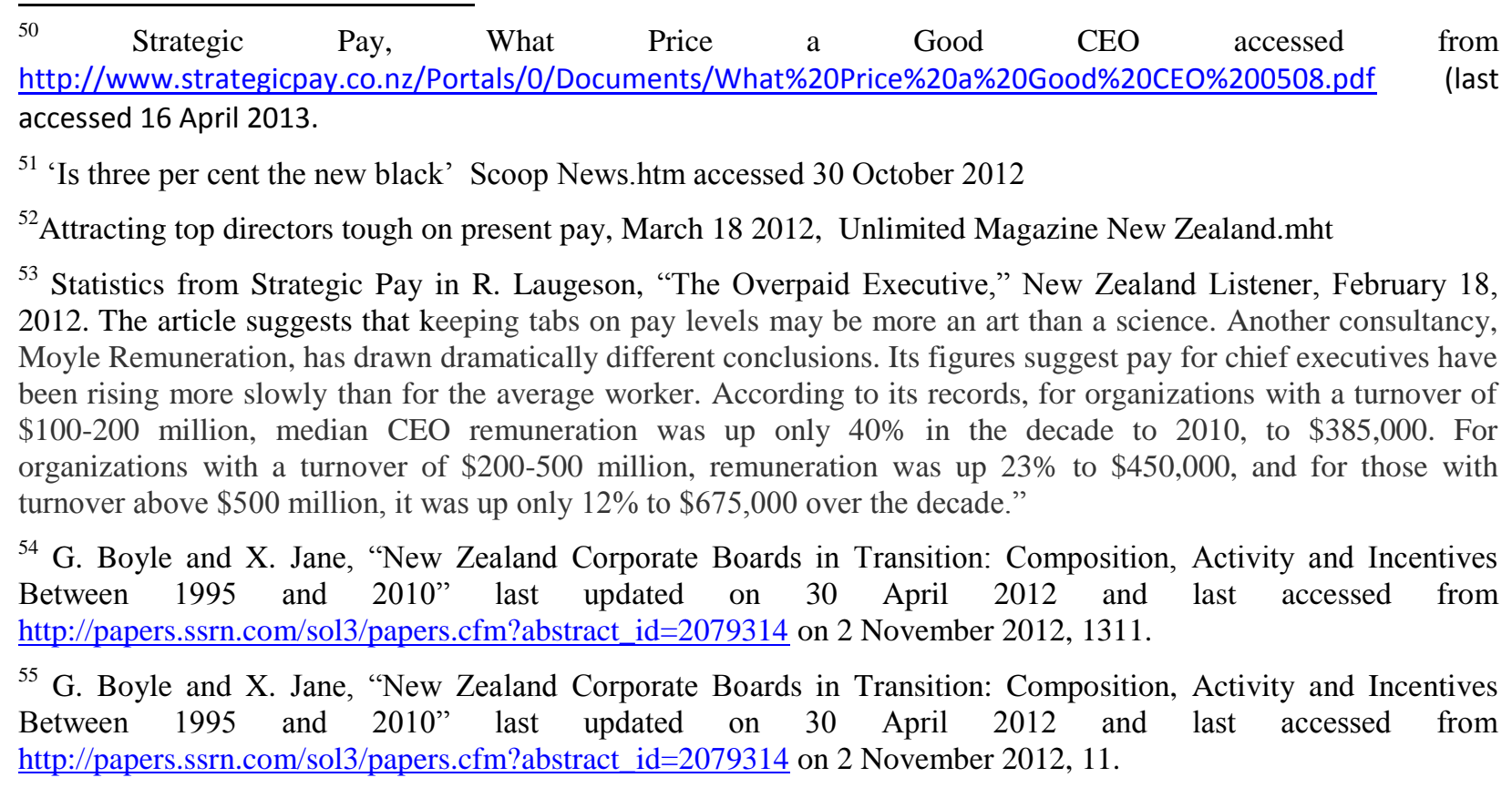


In common with other jurisdictions, the escalation of executive remuneration in New Zealand has attracted its share of trenchant criticism. A recent article suggests that the "rising tide of corporate pay has helped float executive boats elsewhere in the economy" highlighting the recent march by 4000 people protesting a $\$ 68,000$ pay rise awarded to the Christchurch city council chief executive while Christchurch is going through the earthquake recovery process. ${ }^{56}$ The article suggests that increases have "sprung out of a culture that has elevated leadership as being the critical ingredient in the success or failure of an enterprise" and argues that "many ordinary workers find it difficult to comprehend how that worth is actually calculated, and have a sneaking suspicion that the link between effort and reward has become, at best, tenuous. "57 A retired remuneration consultant spoke out in the press recently about the practice of using market data to justify pay packets and drive up executive compensation saying that there was an "overt movement" by many employers to pay salaries "at or above median." 58 These observations are supported by the experience in other jurisdictions where greater levels of disclosure have led to acceleration in levels of executive remuneration. ${ }^{59}$

Other commentators have focused on the lack of connection between executive pay levels and corporate performance. One such comment stated:

"A second theme mentioned was the irresponsibly high level of directors' remuneration in the larger companies in recent years, which often seems to go up in leaps out of all proportion to any increase in living costs and to do so however badly the corporation has been performing. I fear that there may be limits here to what can be accomplished by tinkering with the rules of law: perhaps if the captains of industry and commerce in question were reminded that "governance" in 1600 meant "wise self-command", we might see moves towards appropriate restraint." 60

If accepted, this line of thought argues in favor of adopting Say on Pay, or even more stringent measures, to improve the connection between pay and performance.

Much of the media coverage is tempered with an acceptance that if New Zealand firms are to attract high performing executives, high and escalating remuneration is an inevitable cost. ${ }^{61}$

\footnotetext{
${ }^{56}$ R. Laugeson, "The Overpaid Executive” New Zealand Listener, February 18, 2012. Interestingly the CEO later agreed to forgo the pay increase.

${ }^{57}$ R. Laugeson, “The Overpaid Executive” New Zealand Listener, February 18, 2012.

${ }^{58}$ C. A. Christopher, "Data helping ramp up exec pay" The New Zealand Herald, 26 November 2012.

59 See discussion in R. Thomas, "International Executive Pay: Current Practices and Future Trends" in K. DauSchmidt, S. Harris and O. Lobel (eds) Labor and Employment Law and Economics, Edgar Elgar, 2009, at 183, 212215.

${ }^{60}$ L Sealy, “Corporate Governance and Directors’ Duties” (1995) 1 NZBLQ 92, at p.93.

${ }^{61}$ M. Slade, "Attracting top directors tough on present pay" Unlimited magazine, March 16 2012. ("Sandy Maier, who currently holds a dozen board positions including four chairmanships, told a gathering of chief financial officers in Auckland yesterday that Kiwi directors were paid a third less than their Australian counterparts, after adjustments for size and risk. "There's no reason for it.") "Aussie directors get twice Kiwi pay" National Business Review, 27 July 2005. Brian Gaynor, "Shareholders must battle inequality" 28 January, 2012, "The US sets a precedent for the rest of the world because boards of directors in other countries employ consultants to look at
} 
Remuneration of CEOs of Banks has attracted opprobrium largely because the Banks being Australian owned and highly profitable are perceived to be taking money out of Kiwi pockets. The most outrage is reserved for high compensation and particular severance payments for CEOs in companies that are perceived to have under-performed. ${ }^{62}$ Like other jurisdictions, it is often suggested that CEO remuneration be benchmarked against the remuneration of an "average" worker. $^{63}$

Some, such as the chairwoman of Auckland International Airport and Mighty River Power Joan Withers, advocate more transparency in how boards report on remuneration: "We need a comprehensive piece of work to look at remuneration, at transparency, and how it should be reported and what's best practice" arguing that if boards show clearly how pay is linked to performance, this will lead to more support for the packages. Auckland International Airport, for example, discloses how its chief executive's total remuneration is broken down into base pay

international salaries when assessing the remuneration of their senior executives. So US senior executive pay levels quickly set a precedent for the rest of the world because consultants take these into account when advising non-US boards. This process ratchets-up salaries in other countries, with Australia being a good example of this. As a result, income inequality across the Tasman, as defined by the OECD, has escalated dramatically over the past 30 years. Australian directors argue that they have to pay international salaries to keep their top executives and this means they follow US trends. In addition, the share registries of nearly all the major Australian companies are dominated by institutions, rather than individuals. Many of these institutions are not long-term owners, as demonstrated by their aggressive selling of shares in Billabong, Kathmandu, and other companies when these ASX-listed entities announced recent profit downgrades. New Zealand follows Australia and the remunerations of our senior executives are rapidly ascending as a result."

${ }^{62}$ C. Adams, "Big pay rises for bosses," The New Zealand Herald, May 7 2010, (“Almost half New Zealand's chief executives received pay rises last year - with a median increase of 5 per cent - despite the worldwide recession and many workers enduring salary freezes. Shareholders Association chairman Bruce Sheppard said he was also surprised. "I have no problem with CEO pay going up if they deliver on the performance criteria the board set for them, but I can't see too much rationale to increase base pay," he said."), B Gaynor , "Tread carefully with director fee increases" 22 October, 2011, ("Protest and poor performance will make pay a major issue. Director fee increases are expected to be a major issue at upcoming annual meetings. This is because a number of companies are asking shareholders to approve substantial fee increases even though many of these companies have had disappointing sharemarket performances. In addition, the Occupy Wall St campaign shows there is increasing opposition to excessive corporate remuneration. In light of this, shareholders have to ask themselves what is the appropriate remuneration for non-executive company directors."), B Gould, "Time to break unfair bonus culture" The New Zealand Herald, 3 September 2009, ("Eyebrows and ire were both raised by recent reports of big bonuses contributing to even bigger remuneration packages - paid out to the executives of some of our leading companies. Even when those companies had seen profit margins fall substantially.")

63 “CEO pay packets 9.9pc fatter, "Dominion Post, 20 August 2012 ("The average base salary for chief executives rose $\$ 28,311$ or 9.9 per cent last year to $\$ 315,000$ according to the latest Strategic Pay survey of 3674 Kiwi executives. Somebody working full time on the minimum wage of $\$ 12.57$ an hour would earn $\$ 26,145$ a year."), "Because they're worth it?" Unlimited magazine, 23 August 2011 ("The pay divide between NZ CEOs and employees is not excessive compared to overseas counterparts, but if the gap widens it may start to matter."), G. Shirtcliff, "Executive pay may be caught in an upward spiral," The New Zealand Herald, 2 September 2011 ("The boss has always earned a multiple of what the average worker earns. But over the past 15 years, that multiple has increased. A recent survey estimates that NZX-listed companies now pay their CEOs an average 18 times what they pay the average worker."). 
and incentive pay. ${ }^{64}$ The New Zealand Shareholders' Association is less sanguine; arguing the pendulum of power in organizations has shifted too far in favor of management. ${ }^{65}$

In other jurisdictions, proxy advisory firms such as ISS assist institutional shareholders in informing themselves about executive pay. Often they will interact with boards about identified issues in relation to executive pay. At present, there are no third party voting advisory services based in New Zealand. This means that institutional investors in New Zealand must rely on their own research or a sharebroker or other analysts to inform themselves about executive pay. This is likely to pose a barrier to strong collective voting behavior by these investors and impede the effectiveness of Say on Pay.

The Government shows no signs of moving towards taking steps that might curb executive remuneration. The Finance Minister Bill English recently said, "We don't believe there's a significant problem and I think companies will be picking up the shift in public views about what people get paid right at the top end." ${ }^{, 66}$ Given this position, the prospects for significant change to the legal and corporate governance rules for executive remuneration in New Zealand seem bleak at the moment. However, if there were forceful arguments that Say on Pay would result in beneficial changes for shareholders in New Zealand corporations, perhaps the government would shift its view.

In the next section, to help sort out the pros and cons of Say on Pay, we recap the academic debate that has been ongoing in other countries over the value of that innovation.

\section{Academic Arguments about Say on Pay $^{67}$}

Prior to its enactment in the U.K. and elsewhere, there was an active academic debate about whether a required shareholder vote on executive pay was a good idea and whether it would be effective. The debate regarding the effects of Say on Pay revealed a variety of questions and proposed answers, largely stemming from: 1) different attitudes about whether and how executive pay was a problem; 2) the advocates' varying philosophies toward the role of shareholder voting; and 3) differences over the conclusions to draw from the existing evidence on Say on Pay. ${ }^{68}$

Academics accept that an advisory shareholder vote on corporate pay policies would alter the shareholder role in corporate governance. ${ }^{69}$ Whether that was viewed as a good thing, or a bad one, varied along ideological lines. Academics opposing shareholder activism concluded that

\footnotetext{
${ }^{64}$ Ibid; G. Vaughan, "ANZ, BNZ and Westpac CEOs paid a combined NZ\$12 million; Finsec floats idea of executive salary controls," 17 November 2010, New Zealand Herald.

${ }^{65}$ Ibid.

${ }^{66}$ R. Laugeson, The Overpaid Executive,” New Zealand Listener, February 18, 2012.

${ }^{67}$ The next two sections draw heavily on prior work of one of the authors. See Randall S. Thomas, Alan R. Palmiter and James F. Cotter, "Dodd-Frank's Say on Pay: Will It Lead to a Greater Role for Shareholders in Corporate Governance?”(2012) 97 Cornell L. Rev. 1213.

${ }^{68}$ Ibid at 1226.

${ }^{69}$ Thomas et al., supra at note $67,1228$.
} 
Say on Pay would undermine the efficiency of a "board centrism." 70 On the other hand, academics in favor of Say on Pay see it as a shift to shareholder primacy. ${ }^{71}$

\section{Will Say on Pay shift the balance of power in the corporation?}

Advocates believe Say on Pay will result in greater efficiency and social responsiveness as the mechanism provides more transparency and accountability. Say on Pay, in their eyes, would help boards negotiate CEO pay packages more effectively on behalf of shareholders. ${ }^{72}$ The skeptics, on the other hand, claimed that a shareholder vote on executive pay would disturb the balance of authority between the board of directors and the company's shareholders. ${ }^{73}$ One critic argued that Say on Pay would undermine the efficiency of the "board centric" corporation, the "command" mode of organization chosen by US public corporations. ${ }^{74}$ One response to this claim was that a mandatory Say on Pay vote would not change the existing allocation of shareholder and board power. ${ }^{75}$ Shareholders already have the ability to express their concerns about executive pay by speaking directly with management, the casting a vote against or withholding of a vote for directors sitting on compensation committees with undesirable pay policies, and shareholder proposals seeking voluntary company adoption of Say on Pay. ${ }^{76}$ One rejoinder was that because it was already possible to have such a vote without it being mandatory, that a required vote would create few benefits but was certain to produce additional costs. $^{77}$ In congressional testimony comments on early Say on Pay bill, for example, a wellknown defender of existing executive pay practices stated:

[Dodd Frank] would mandate a non-binding shareholder vote to approve the compensation of executives for every company every year. Companies with problems

\footnotetext{
${ }^{70}$ Ibid

${ }^{71}$ Ibid.

72 Lucian Bebchuk \& Jesse Fried, "Written Testimony: Hearing on Empowering Shareholders on Executive Compensation Before the H. Comm. on Financial Services" (March 8, 2007), available at http://www.shareholderforum.com/op/Library/20070308_Bebchuk.pdf; Stephen Davis, "Does Say on Pay Work? Lessons on making CEO compensation accountable,"1622 PLI/Corp 33, 46 (2007). Policy Briefing, The Millstein Center for Corporate Governance and Performance, Yale School of Management, New Haven, CT (2007).

${ }^{73}$ Statement of Congressman Michael Castle, Compensation Structure and Systemic Risk: Hearing Before the H. Comm. on Fin. Serv., 111 Cong. Serial No. 111-42 at 5 (June 11, 2009) (pointing out that stockholders have right to change directors); Statement of Congressman Jeb Hensarling, Compensation Structure and Systemic Risk: Hearing Before the H. Comm. on Fin. Serv., 111 Cong. Serial No. 111-42 at 7 (June 11, 2009) at 5, 7

${ }^{74}$ See Stephen M. Bainbridge, "The Corporate Governance Provisions of Dodd-Frank" UCLA School of Law, LawEcon Research Paper No. 10-14 (October, 27 2010), available at http://ssrn.com/abstract=1698898.

${ }^{75}$ Se $e$ Letter from Timothy J. Bartl, Senior Vice President \& Gen. Counsel, Ctr. on Exec. Comp., to Elizabeth M. Murphy, Sec'y, SEC (Sept. 8, 2009), available at www.sec.gov/comments/s7-12-09/s71209-46.pdf ..

${ }^{76}$ See Center On Executive Compensation, "Comments on SEC Proposed Rule Regarding Shareholder Approval of Executive, Compensation of TARP Recipients” Release No. 34-60218; File No. S7-12-09 (Sept. 8, 2009), available at www.sec.gov/comments/s7-12-09/s71209-46.pdf.

${ }^{77}$ Empowering Shareholders on Executive Compensation: Hearing on H.R. 1257 Before the H. Comm. on Fin. Servs., 110th Cong. 126 (testimony of Steven N. Kaplan, Neubauer Family Professor of Entrepreneurship and Finance, University of Chicago) [hereinafter Kaplan Testimony], available at http:// www.gpo.gov/fdsys/pkg/CHRG-110hhrg35402/pdf/CHRG-110hhrg35402.pdf.
} 
will have a vote and, presumably, will receive a negative vote. But this is almost exactly what happens under the current system. So, it is not clear to me that the new bill would create any benefits. . . . The increased transparency for CEO pay required by the new SEC disclosure rules should further reduce any remaining unwise compensation practices. $^{78}$

\section{Are shareholders competent to evaluate executive pay?}

Investors' ability to determine when pay was appropriate was a second important issue. Advocates believed that shareholders would be able to discern and vote down poorly designed pay packages. ${ }^{79}$ Busy institutional investors would rely on ISS and the other proxy advisory firms for help when necessary. Critics were less sure that shareholders would be able to discern differences in pay plans. Some pointed to the first six years of experience in the U.K., where, when pay policies were put to a vote, shareholders invariably approved executive pay packages and were doubtful about shareholders' abilities. ${ }^{80}$ The thrust of their skepticism rested on the observation that given the vast number of companies most institutions invested in, it was unlikely that U.S. shareholders would give individualized attention to particular compensation schemes. ${ }^{81}$ This argument was bolstered by the relatively low levels of voting support for most Say on Pay shareholder proposals. The statistics showed that the number of shareholder proposals seeking an advisory vote on pay had been relatively constant and shareholder support had leveled off at about $42 \% .^{82}$ One critic summarized the empirical evidence as follows:

Just last year, seven proposals for say-on-pay were introduced at companies in 2008, ten of them were successful.

The average vote was a 60 percent vote against say-on-pay by the shareholders. At financial companies it is even higher. 70 percent was the average vote against say-on-pay at financial companies. So shareholders ... at the majority of companies in a very strong majority way have expressed dissatisfaction with say-on-pay proposals. ${ }^{83}$

\footnotetext{
78 Testimony of Steven N. Kaplan: Hearing on "Empowering Shareholders on Executive Compensation" and H.R. 1257, the "Shareholder Vote on Executive Compensation Act" Before the H. Comm. on Financial Services at 5 (March 8, 2007), available at http://www.law.yale.edu/documents/pdf/cbl/KaplanTestimonyFinancialServices.pdf

${ }^{79}$ Lucian Bebchuk \& Jesse Fried, supra note 49, at 1-2 (concluding that Say on Pay votes "will annually provide companies with valuable information about how their shareholders view company performance in this critical area").

${ }^{80}$ Jeffrey N. Gordon, "Say on Pay": Cautionary Notes on the U.K. Experience and the Case for Shareholder Opt-In" 46 Harv. J. on Legis. 323, 341 (2009) (explaining that "shareholders invariably approve the Directors Remuneration Report, with perhaps eight turndowns across thousands of votes over a six-year experience").

${ }^{81}$ Ibid.

${ }^{82}$ Ibid. at 339 ("The number of [Say on Pay] proposals grew only moderately [in 2008], to seventy, and the level of shareholder support has remained at the same level, approximately forty-two percent").

${ }^{83}$ Compensation Structure and Systemic Risk: Hearing Before the H. Comm. on Financial Services, 111 Cong. Serial No. 111-42 at 52-53. (June 11, 2009) (testimony of Professor Verret), available at http://www.gpo.gov/fdsys/pkg/CHRG-111hhrg52398/pdf/CHRG-111hhrg52398.pdf.
} 
While others criticized Say on Pay would be used to push political ideologies by activist shareholders, ${ }^{84}$ however, the empirical evidence on this claim is indeterminate. ${ }^{85}$

\section{Does Say on Pay increase the power of proxy voting advisory firms?}

Another potential criticism is that Say on Pay increases the power of proxy advisory firms, whose recommendations would be followed blindly by institutional shareholders, ${ }^{86}$ while management's discretionary authority is undermined. ${ }^{87}$ To elaborate, if institutional shareholders rely heavily on proxy advisory firms, those companies will wield undue influence over voting on executive pay. ${ }^{88}$ Further, activist shareholders will focus selectively on a narrow range of compensation schemes, which proxy advisory firms identify as suspect. Finally, these voting advisors' recommendations might be biased if the firm both provides voting advice to shareholders on pay packages and while simultaneously consulting with companies on their pay policies. ${ }^{89}$

Supporters are quick to point out that proxy advisory firms serve the purpose of helping institutional (and other) shareholders use their voting power in a coordinated way to overcome collective action problems. ${ }^{90}$ As one prominent academic observed, "When institutional investors follow ISS [vote recommendations] en masse, directors of public corporations can expect to see $20 \%, 30 \%$ even $50 \%$ of their company's shares being voted not as the directors

\footnotetext{
${ }^{84}$ Testimony of Steven N. Kaplan: Hearing on "Empowering Shareholders on Executive Compensation" and H.R. 1257, the "Shareholder Vote on Executive Compensation Act" Before the H. Comm. on Financial Services at 5 (March 8, 2007), available at http://www.law.yale.edu/documents/pdf/cbl/KaplanTestimonyFinancialServices.pdf.

${ }^{85}$ Compare Jie Cai \& Ralph Walking, "Shareholders' Say on Pay: Does It Create Value?” J. Fin. \& QuAntitative ANALYSIS (forthcoming), available at $\mathrm{http}$ ://papers.ssrn.com/sol3/papers.cfm?abstract id=1342656 at 32-33 (finding negative market reaction to pay proposals sponsored by labour unions) with Yonica Ertimur, Fabrizio Ferri \& Volkan Muslu, Shareholder Activism and CEO Pay, Review of Financial Studies 34 (forthcoming), available at http://papers.ssrn.com/sol3/papers.cfm?abstract id=1443455), at 2-3. (finding that unions are not more likely to target firms that are unionized or engaged in disputes with unions). See generally, Stewart J. Schwab \& Randall S. Thomas, "Realigning Corporate Governance: Shareholder Activism by Labor Unions" (1998) 96 Mich. L. Rev. 1018 for a discussion of labor union shareholder activism.

${ }^{86}$ Stephen M. Bainbridge, “The Corporate Governance Provisions of Dodd-Frank" UCLA School of Law, Law-Econ Research Paper No. 10-14 (October, 27 2010), available at http://ssrn.com/abstract=1698898, at 4-5 (also arguing that RiskMetrics, the most important proxy advisory firm, faces conflicts its dual role of both advising and rating companies on corporate governance matters).

${ }^{87}$ Stephen N. Bainbridge, "Dodd-Frank: Quack Federal Corporate Governance Round II" (2011) 95 Minn. L. Rev. $1779,1815$.

${ }^{88}$ See Jeffrey N. Gordon, Essay, "Say on Pay": Cautionary Notes on the U.K. Experience and the Case for Shareholder Opt-In," (2009) 46 HARV. J. ON LEGIS. 323, 351-52.

${ }^{89}$ See A Call for Change in the Proxy Advisory Industry Status Quo, at 7-8 (published by the Center on Executive Compensation) (January 2011) ("Proxy Advisory White Paper"), http://online.wsj.com/public/resources/documents/ProxyAdvisoryWhitePaper02072011.pdf.

${ }^{90}$ This coordination function is illustrated by the Say on Pay voting during the 2011 proxy season, when all of the companies that failed to receive majority support for their Say on Pay resolutions also had received an "against" recommendation by the ISS. See infra.
} 
recommend, but as ISS recommends." 91 Voting advisory firms create and periodically revise "best practices" voting guidelines based on input from their clients, which fosters institutional shareholder activism and helps those clients with fiduciary obligations to vote in a way that protects plan assets. ${ }^{92}$ In the absence of proxy voting advisors, institutional shareholders bear the costs of performing their own research. ${ }^{93}$ This increased costs leads to the underproduction of important monitoring and voting information. ${ }^{94}$

Proxy voting advisors may also serve as representatives for their clients' interests, so that companies negotiate directly with the ISS to make changes to their compensation practices and thereby position themselves to get favorable voting recommendations. ${ }^{95}$ In this way, the proxy voting advisors serve as a monitor on behalf of shareholders of company activities, reviewing director performance, shareholder proposals, and voting contests, and formulating advice to shareholders on how to vote. ${ }^{96}$

\section{Can Say on Pay slow the growth of executive pay?}

Critics of the existing executive pay system claim that Say on Pay could dampen the spiral in executive pay. A strong negative shareholder Say on Pay vote might reduce excesses in executive pay according to some activist institutional shareholders. ${ }^{97}$ Thus, Say on Pay votes might make directors "more attentive" to shareholders and "deter some egregious compensation arrangements." ${ }^{98}$ Not all scholars agreed. Professors Cheffins and Thomas argue U.S. shareholders would use Say on Pay as a tool to vote down only those pay policies that "deviated far from the norm." "99 This, they predicted, was insufficient to support some shareholders' hopes that Say on Pay would stifle the upward spiral in executive pay. ${ }^{100}$

91 Lynn A. Stout, Why Should ISS Be The New Master Of The Corporate Governance Universe? 14-15, CORPORATE GOVERNANCE, Dow Jones Financial Information Services (Jan. 4, 2006).

92 Paul Rose, “The Corporate Governance Industry”,(2007) 32 J. Corp. L. 887, at pp 899-903 (describing business and operations of ISS).

${ }^{93}$ R C Clark, Corporate Law (Norwood Beveridge,1986) 389-94

${ }^{94}$ See R C Clark, Corporate Law (Norwood Beveridge, 1986) 389-94 (classic description of shareholder voting in public corporations, which presents collective action problems similar to the "prisoner's dilemma").

95 See Robin Sidel et al., ISS Is Put in the Spotlight as H-P Claims Victory, Wall St. J., Mar. 20, 2002, at C20 (stating that ISS's recommendation for the Hewlett-Packard and Compaq merger 'helped bolster H-P's position in one of the most contentious proxy battles in recent years").

96 Stephen J. Choi \& Jill E. Fisch, "How To Fix Wall Street: A Voucher Financing Proposal for Securities Intermediaries" (2003) 113 Yale L.J. 269, at pp 294-95 (describing role and influence of ISS, which operates on a limited budget).

97 Archie B. Carroll \& Ann K. Buchholtz, "Business and Society: Ethics and Stakeholder Management" $812-13$ (2008) (describing AFSCME's decision to seek Say on Pay vote at Home Depot).

98 Lucian A. Bebchuk \& Holger Spamann, "Regulating Bankers' Pay" (2010) 98 Geo. L.J. 247, at p 275 (commenting on possible effects of Say on Pay for TARP recipients).

${ }^{99}$ Brian Cheffins \& Randall Thomas, "Should Shareholders Have A Greater Say Over Executive Pay?: Learning from the U.S. Experience” (2001) 1 J. OF CORP. L. STUD. 277, at p 310.

100 Lynn A. Stout, Why Should ISS Be The New Master Of The Corporate Governance Universe? 14-15, CORPORATE GOVERNANCE, Dow Jones Financial Information Services (Jan. 4, 2006). 
One critic claimed that caution should be exercised in adopting a shareholder vote because of the U.K. experience with Say on Pay. ${ }^{101}$ This academic pointed out that during the first six years of Say on Pay in U.K. public companies shareholders had consistently approved any pay package put to a vote, while the upward spiral in U.K. executive pay continued unabated. $^{102}$

\section{Will Say on Pay strengthen the pay-for-performance relationship?}

Most importantly, the academic debate focused on whether Say on Pay would create a stronger link between "pay and performance" and reduce companies' "pay for failure." ${ }^{103}$ A prominent supporter concluded that an advisory vote on executive pay would allow shareholders to express their views on those flawed pay practices that were disconnected from company performance. ${ }^{104}$ In response, some critics of Say on Pay questioned whether pay and performance are actually divorced. ${ }^{105}$ One claimed:

While there have clearly been abuses and unethical CEOs, pay for the typical CEO appears to be largely driven by market forces. ... Firms with CEOs in the top decile of

${ }^{100}$ Paul Rose, "The Corporate Governance Industry" (2007) 32 J. Corp. L. 887, 899-903 (describing business and operations of ISS).

${ }^{100}$ R C Clark, Corporate Law (Norwood,Beveridge, 1986) 389-94 .

${ }^{100}$ See ibid (classic description of shareholder voting in public corporations, which presents collective action problems similar to the "prisoner's dilemma").

${ }^{100}$ See Robin Sidel et al., ISS Is Put in the Spotlight as H-P Claims Victory, Wall St. J., Mar. 20, 2002, at C20 (stating that ISS's recommendation for the Hewlett-Packard and Compaq merger "helped bolster H-P's position in one of the most contentious proxy battles in recent years").

${ }^{100}$ Stephen J. Choi \& Jill E. Fisch, "How To Fix Wall Street: A Voucher Financing Proposal for Securities Intermediaries" (2003) 113 Yale L.J. 269, 294-95 (describing role and influence of ISS, which operates on a limited budget).

${ }^{100}$ Archie B. Carroll \& Ann K. Buchholtz, Business and Society: Ethics and Stakeholder Management (2008) 81213 (describing AFSCME's decision to seek Say on Pay vote at Home Depot).

${ }^{100}$ Lucian A. Bebchuk \& Holger Spamann, “Regulating Bankers' Pay,” (2010) 98 Geo. L.J. 247,275 (commenting on possible effects of Say on Pay for TARP recipients).

${ }^{100}$ Ibid at 310,315 .

${ }^{101}$ Jeffrey N. Gordon, "Say on Pay": Cautionary Notes on the U.K. Experience and the Case for Shareholder Opt-In, (2009) 46 Harv. J. on Legis. 325.

${ }^{102}$ See ibid. at 341 ("shareholders invariably approve the Directors Remuneration Report, with perhaps eight turndowns across thousands of votes over a six-year experience").

${ }^{103}$ See generally Fabrizio Ferri \& David A. Maber, "Say on Pay Votes and CEO Compensation: Evidence from the UK" Rev. Fin. (forthcoming) (manuscript abstract), available at http://papers.ssrn.com/sol3/papers.cfm?abstract_ id=1420394 (last updated Nov. 25, 2011).

${ }^{104}$ Lucian Bebchuk \& Jesse Fried, Written Testimony: Hearing on Empowering Shareholders on Executive Compensation Before the H. Comm. on Financial Services (March 8, 2007), available at http://www.shareholderforum.com/op/Library/20070308_Bebchuk.pdf.

${ }^{105}$ Stephen N. Bainbridge, “Dodd-Frank: Quack Federal Corporate Governance Round II,” (2011) 95 Minn. L. Rev. 1779, 1809 (surveying literature on whether US executive pay and concluding "core premise behind say-onpay remains, at best, unproven"). 
actual pay earned stock returns that were $90 \%$ greater than those of other firms in their industries over the previous 5 years. Firms with CEOs in the bottom decile of actual pay underperformed their industries by almost $40 \%$ in the previous 5 years. The results are qualitatively similar if we look at performance over the previous three years or previous year. There can be absolutely no doubt that the typical CEO in the U.S. is paid for performance. ${ }^{106}$

Some empirical studies have focused on this question. One detailed study of the U.K. Say on Pay experience looked at its effect on both disclosed changes in executive compensation and estimated undisclosed changes. ${ }^{107}$ The authors concluded:

[S]ay on pay results in greater penalties for poor performance [in U.K. public companies]. In particular, most firms experiencing high voting dissent respond by removing controversial provisions that investors criticize as "rewards for failure" (e.g. large severance payments). The threat of voting dissent also seems to have an effect: many firms experiencing low dissent remove controversial provisions before the vote. Our regression tests document an increase in the pay-for-poor-performance sensitivity, particularly in firms experiencing high dissent and firms with "excess" CEO pay before the legislation. ${ }^{108}$

\section{Summary of academic arguments over Say on Pay}

Say on Pay provisions are contentious. In the U.S. debate, supporters anticipated that Say on Pay would "empower shareholders to vote down pay structures that encourage excessive risktaking," 109 would make "corporate management more accountable to shareholders," ${ }^{110}$ would help arrest the upward spiral in CEO pay, ${ }^{111}$ and would compel corporate boards to align pay with the corporation's financial performance. ${ }^{112}$ In short, supporters of Say on Pay predicted a

\footnotetext{
${ }^{106}$ Testimony of Steven N. Kaplan: Hearing on "Empowering Shareholders on Executive Compensation" and H.R. 1257, the "Shareholder Vote on Executive Compensation Act" Before the H. Comm. on Financial Services at 5 (March 8, 2007), available at http://www.law.yale.edu/documents/pdf/cbl/KaplanTestimonyFinancialServices.pdf, at 1- 2 (describing paper with Josh Rauh that looked at CEO pay from 1999 to 2004).

${ }^{107}$ Fabrizio Ferri \& David A. Maber, "Say on Pay Votes and CEO Compensation: Evidence from the UK" Rev. Fin. (forthcoming) (manuscript abstract), available at http://papers.ssrn.com/sol3/papers.cfm?abstract_id=1420394 (last updated Nov. 25, 2011).

${ }^{108}$ Ibid..

109 Statement of Congressman Barney Frank, Compensation Structure and Systemic Risk: Hearing Before the H. Comm. on Fin. Serv., 111 Cong. Serial No. 111-42 at 1-3 (June 11, 2009); Statement of Congressman David Scott, Compensation Structure and Systemic Risk: Hearing Before the H. Comm. on Fin. Serv., 111 Cong. Serial No. $111-$ 42 at 4-5 (June 11, 2009) (arguing that executive pay systems have "no downside" to failure).

110 Statement of Gene Sperling, Counselor to the Secretary of the Treasury, U.S. Dept. of Treasury, Compensation Structure and Systemic Risk: Hearing Before the H. Comm. on Fin. Serv., 111 Cong. Serial No. 111-42 at 12-14 (June 11, 2009).

${ }^{111}$ H.R. Rep. No. 110-88, at 2 (2007) (accompanying earlier Say on Pay provision, which noted that median CEO pay had grown to \$13.5 million in FY 2005 at the 1400 largest US public companies).

112 Statement of Congressman David Scott, Compensation Structure and Systemic Risk: Hearing Before the H. Comm. on Fin. Serv., 111 Cong. Serial No. 111-42 at 4-5 (June 11, 2009), at 4-5.
} 
mandatory shareholder vote would alter the balance of power in US public corporations -especially over executive pay -- moving it decidedly toward shareholders. As one government official said:

You are empowering shareholders with the ability to have stronger oversight. You are forcing the company to think more seriously about what they do, how it will be perceived and not just to go on automatic pilot doing practices that are not defensible simply because of their peer group is doing it. ${ }^{113}$

Opponents argue that Say on Pay would cause government to intrude in the boardroom ${ }^{114}$ and put executive compensation in the "hands of government bureaucrats;" ${ }^{115}$ would upset the traditional distribution of power between boards and shareholders; ${ }^{116}$ would make it harder for companies, particularly in financial sector, to hire and retain the "best and brightest;" ${ }^{117}$ would be prohibitively expensive, particularly for smaller companies, to report their pay plans and give shareholders a vote; ${ }^{118}$ and would lead to activist shareholders favoring a narrow range of compensation programs, pushing U.S. public companies to adopt one-size-fits-all compensation plans. ${ }^{119}$ In short, these critics predicted Say on Pay would impose costs that outweigh its benefits.

Section III next looks at the practical effects of Say on Pay in the U.K. and U.S. to provide additional insights into how Say on Pay might affect New Zealand if it was implemented.

\section{Lessons from the U.K. and U.S. experience}

\footnotetext{
113 Statement of Gene Sperling, Counselor to the Secretary of the Treasury, U.S. Dept. of Treasury, Compensation Structure and Systemic Risk: Hearing Before the H. Comm. on Fin. Serv., 111 Cong. Serial No. 111-42 at 12-14 (June 11, 2009)., at 38.

${ }^{114}$ Statement of Congressman Spencer Bachus, Compensation Structure and Systemic Risk: Hearing Before the H. Comm. on Fin. i 111 Cong. Serial No. 111-42 at 3-4 (June 11, 2009).

115 Statement of Congressman Scott Garrett, Compensation Structure and Systemic Risk: Hearing Before the H. Comm. on Fin. Serv., 111 Cong. Serial No. 111-42 at 9 (June 11, 2009); Bachus statement, supra note 35, at 3 (arguing that the government should not mandate private compensation policies).
}

116 Statement of Congressman Michael Castle, Compensation Structure and Systemic Risk: Hearing Before the H. Comm. on Fin. Serv., 111 Cong. Serial No. 111-42 at 5 (June 11, 2009) (pointing out that stockholders have right to change directors); Statement of Congressman Jeb Hensarling, Compensation Structure and Systemic Risk: Hearing Before the H. Comm. on Fin. Serv., 111 Cong. Serial No. 111-42 at 7 (June 11, 2009) (arguing that executive pay is probably a "nonexistent problem," but shareholders should vote for new management).

117 Statement of Congressman Judy Biggert, Compensation Structure and Systemic Risk: Hearing Before the H. Comm. on Fin. Serv., 111 Cong. Serial No. 111-42 at 7 (June 11, 2009).

${ }^{118}$ Statements of Congressmen Garrett and Alvarez, Compensation Structure and Systemic Risk: Hearing Before the H. Comm. on Fin. Serv., 111 Cong. Serial No. 111-42 at 32 (June 11, 2009) (suggesting larger firms could more easily bear costs of Say on Pay votes than smaller firms, which "do a better job of aligning risk and rewards").

119 Stephen N. Bainbridge, “Dodd-Frank: Quack Federal Corporate Governance Round II" (2011) 95 Minn. L. Rev. 1779, 1810. 
After the implementation of Say on Pay in a number of countries, it has become possible to observe its effects in practice. In this section, we examine some of this evidence in an effort to shed some light on how the advisory vote has affected compensation practices, corporate governance and pay levels in two important countries: the United Kingdom and the United States. Other countries, Australia and the Netherlands in 2005, have also enacted Say on Pay legislation. ${ }^{120}$ The Dutch law calls for a binding shareholder vote, not merely an advisory one, but the vote does not necessarily happen annually and the shareholder vote concerns compensation policies, not a retrospective pay report. ${ }^{121}$ Following the Dutch model, Sweden in 2006 and Norway in 2007 also enacted legislation requiring a binding shareholder vote on compensation policies. ${ }^{122}$ We do not specifically address these other countries' experiences in this paper though.

\section{The Evidence from the U.K.}

The U.K. has had the longest experience with Say on Pay of any country. In 2002, the United Kingdom became the first country to mandate a shareholder vote on executive pay. ${ }^{123}$ U.K.-incorporated listed companies were required to submit a Director's Remuneration Report annually to shareholders and hold a non-binding shareholder vote on that report. ${ }^{124}$ Even after the enactment of non-binding Say on Pay, world events brought executive compensation to the front page of newspapers and enraged the public in the U.K. and the EU more broadly. ${ }^{125}$ Lehman Brothers historic collapse in the U.S. and the Royal Bank of Scotland's crisis "reinvigorated the inquiry about what is appropriate remuneration in the EU." ${ }^{126}$ Richard Lambert, the Director-

\footnotetext{
${ }^{120}$ See Regan Adamson \& Daniel Lumm, "Shareholder Democracy and the Say on Pay Movement: Progress, But How Do You Define Success?" 6 (Working Paper, Wake Forest L. Rev.), available at http://lawreview.law.wfu.edu/files/2011/02/working.2009.adamson.lumm_.pdf. The Corporations Amendment (Improving Accountability on Director and Executive Remuneration) Act 2011, in sections 250R(2), 250U-V, mandates that if at two consecutive meetings over $25 \%$ of shareholders vote against the directors' remuneration package, at the second AGM the shareholders will have to vote on a spill motion. If the spill motion receives approval by a simple majority, the directors have to stand for election again within 90 days. This is known as the "two strikes" regime.
}

${ }^{121}$ Regan Adamson \& Daniel Lumm, "Shareholder Democracy and the Say on Pay Movement: Progress, But How Do You Define Success?" 6 (Working Paper, Wake Forest L. Rev.), available at http://lawreview.law.wfu.edu/files/2011/02/working.2009.adamson.lumm_.pdf. at 6.

122 Ibid.

${ }^{123}$ Steven Deane, "Say on Pay: Results from Overseas," Corporate Board, Jul/Aug 2007, Vol. 28 Issue 165, at 11, 12.

124 See Sudhakar Balachandran, Fabrizio Ferri \& David Maber, "Solving the executive compensation problem through shareholder votes? Evidence from the U.K." (Nov. 2007), available at http://www7.gsb.columbia.edu/ciber/sites/default/files/balchandranCIBER_Grant_Paper_UK_Voting.pdf.

125 Marissa Anne Pagnattaro \& Stephanie Greene, "Say on Pay": The Movement to Reform Executive Compensation in the United States and European Union” (2011) 31 Nw. J. INT’L L. \& BUS. 593 , 614 (arguing Europe as a whole experienced a "corporate governance wake-up call," following Dutch company Royal Ahold's overstated earnings, France's Vivendi's pay out of $€ 21$ million in CEO severance pay, and billions left unaccounted at Italy's Parmalat).

${ }^{126}$ Ibid. 
General of the Confederation of British Industry stated, "top executives 'risk being treated as aliens' . . because their pay is so out of step with that of the population at large."

In June 2012, the U.K.'s Department for Business Innovation \& Skills responded, releasing a consultation proposing compensation reporting regulations and implementation of binding Say on Pay in the U.K. for companies with shares on the Financial Services Authority's Official List ${ }^{128}$ as well as all U.K. companies listed on the NYSE, the NASDAQ, or with shares listed in another EEA state, beginning in October 2013. ${ }^{129}$ The proposal was made at "a national level in consultation with companies, shareholders, institutional investors and other interested parties," 130 and is seen by many as a response to the "shareholder spring" which occurred this year. $^{131}$

Initial reports indicate the government's proposal will be included as part of the Enterprise and Regulatory Reform Bill being debated in Parliament, which not only calls for a binding shareholder vote on compensation policies but also increases disclosure requirements. ${ }^{132}$ This section is based on the evidence compiled under the advisory vote system, as the new rules have not yet been implemented and it is too early to determine if the binding vote will have different effects.

In testimony before the American Congress, Professor Coates concluded that the U.K.'s experience with non-binding Say on Pay had been positive:

different researchers have conducted several investigations [on the U.K. Say on Pay experience] ... These findings suggest that say-on-pay legislation would have a positive impact on corporate governance in the U.S. While the two legal contexts are not identical, there is no evidence in the existing literature to suggest that the differences would turn what would be a good idea in the U.K. into a bad one in the U.S. ${ }^{133}$

\footnotetext{
${ }^{127}$ Ibid (citing Jean Eaglesham, "CEOs Risk Being Seen as 'Aliens' Over Pay" Fin. TIMES (Mar. 30, 2010), http://www.ft.com/cms/s/0/853501bc-3c38-11df-b40c-00144feabdc0.html).

${ }^{128}$ Danielle Harris, "UK Reform on Director Pay," GovernANCE Sept. 2012, at 8 (noting that it is irrelevant if the shares have a premium or standard listing).

${ }^{129}$ Ibid DEP’T FOR BUSINESS INNOVATION \& SKILlS, DiRECTORS' PAY: CONSULTATION ON REVISED REMUNERATION REPORTING REGULATIONS 15 (June 2012).

${ }^{130}$ Edward F. Greene, Cleary Gottlieb Steen \& Hamilton LLP, "Binding Shareholder Say-on-Pay Vote in UK," Harv. L. SCh. F. ON CORP. GOVERnANCE \& Fin. Reg. (July 31, 2012, 9:35 AM), http://blogs.law.harvard.edu/corpgov/2012/07/31/binding-shareholder-say-on-pay-vote-in-uk/.

${ }^{131}$ Harris, supra note 79, at 8 . This "shareholder spring" references the observations by commentators that this year shareholders "registered their anger" through negative shareholder votes and forced "some high profile departures" and withdrawal of controversial elements of pay policies. Id.

132 Marissa Anne Pagnattaro \& Stephanie Greene, "Say on Pay": The Movement to Reform Executive Compensation in the United States and European Union" (2011) 31 NW. J. INT'L L. \& BUS. 593

${ }^{133}$ S. Rep. No. 111-176, at 134 (2010).
} 
His testimony drew from studies that compared U.K. pay practices before and after the U.K. Say on Pay mandate. One such study concluded that the new rule had increased pay-forperformance sensitivity at U.K. companies:

Based on a large sample of U.K. firms over the period from 2000 to 2005, we find evidence of enhanced sensitivity of CEO cash compensation to negative operating performance and enhanced sensitivity of CEO total compensation to negative operating and stock performance after the new rule, consistent with widespread calls for less "rewards for failure" that had led to its introduction. ${ }^{134}$

A second study, looking at the impact of the U.K. legislation on stock prices in high-pay companies and actual voting results under the U.K. Say on Pay regime, found a favorable shareholder reaction to the legislation and pay reforms at companies receiving negative votes on their pay practices:

We examine the effect of say on pay regulation in the United Kingdom (U.K.). Consistent with the view that shareholders regard say on pay as a value-creating mechanism, the regulation's announcement triggered a positive stock price reaction for firms with excess CEO pay. U.K. firms responded to negative say on pay voting outcomes by removing controversial CEO pay practices criticized as "rewards for failure" (e.g., generous severance contracts). The sensitivity of pay to poor realizations of performance increased in the post-say on pay period, particularly among firms that experienced high voting dissent and firms with "excess" CEO pay before the regulation. ${ }^{135}$

Recent evidence from the U.K. shows that shareholders there continue to press against high levels of executive remuneration, using the shareholder vote as one of their tools in this battle. ${ }^{136}$

\section{The American Experience}

\section{A. Development of Say on Pay in the U.S.}

Say on Pay in the U.S. grew out of precatory shareholder-sponsored proposals submitted to the company for inclusion on its proxy statement under Rule $14 \mathrm{a}-8 .{ }^{137}$ These early Say on Pay shareholder proposals were uniformly opposed by management, but received significant shareholder support. Management opposed the proposals on the ground that the board of

\footnotetext{
${ }^{134}$ Sudhakar Balachandran, Fabrizio Ferri \& David Maber, "Solving the executive compensation problem through shareholder votes? Evidence from the U.K. "(Nov. 2007), available at http://www7.gsb.columbia.edu/ciber/sites/default/files/balchandranCIBER Grant Paper_UK Voting.pdf., at 1.

${ }^{135}$ Fabrizio Ferri \& David Maber, "Say on Pay Votes and CEO Compensation: Evidence from the UK" available at http://papers.ssrn.com/sol3/papers.cfm?abstract_id=1420394) (first posted April 26, 2010 and last revised October 14, 2011).

${ }^{136}$ David Oakley, "Rebellion Against Executive Pay Kicks in,” Financial Times, August 17, 2012.

${ }^{137}$ Randall S. Thomas, Alan R. Palmiter and James F. Cotter, “Dodd-Frank's Say on Pay: Will It Lead to a Greater Role for Shareholders in Corporate Governance?”, (2012) 97 Cornell L. Rev. 1213..
} 
directors was responsible for setting the terms of pay for the company's top executives. In their eyes, shareholder input would reduce the effectiveness of the board's role.

Initially, boards ignored Say on Pay proposals, even those supported by a majority of shareholders, ${ }^{138}$ but before too long, some companies began voluntarily to hold Say on Pay votes. The level of shareholder voting support for these proposals ranged from 10 to $50 \%$ depending on the company and type of request made in the proposal.

In 2008, in response to public concerns about the financial crisis, Congress put Say on Pay on its legislative agenda. The Emergency Economic Stabilization Act of 2008 (EESA) required that financial firms receiving TARP funds give their shareholders an advisory vote on executive pay. ${ }^{139}$ In 2009, the financial stimulus plan continued in place the Say on Pay requirement for financial firms that had outstanding TARP debts. ${ }^{140}$

To implement this new legislation in 2009 the SEC adopted new rules. ${ }^{141}$ The SEC amended its proxy rules to require TARP recipients to permit a separate shareholder advisory vote on the firm's executive pay. All told, one hundred financial firms held Say on Pay votes during the 2010 proxy season. ${ }^{142}$ The EESA mandate of Say on Pay for financial firms receiving TARP money expanded the shareholder Say on Pay movement, which had already targeted pay practices at certain financial-service firms.

The EESA mandate expanded the pool of firms subject to Say on Pay votes beyond those targeted by shareholders as having "bad" compensation. Not surprisingly, shareholder voting support for these mandatory Say on Pay proposals increased. ${ }^{143}$ In fact, during the 2010 proxy

138 “Companies Ignore "Say on Pay" Votes” Directorship, July 23, 2008, available at http://www.directorship.com/companies-ignore-say-on-pay-votes.

${ }^{139}$ The Troubled Assets Relief Program, established by the Emergency Economic Stabilization Act of 2008 (EESA), required that companies with outstanding funds provide an advisory vote to their shareholders. See EESA $\S 111(\mathrm{e})$, 12 U.S.C. $\S 5221(\mathrm{e})$.

${ }^{140}$ The American Recovery and Reinvestment Act of 2009, while amending some aspects of EESA, left intact the "say on pay" requirements. Pub. L. No. 111-5, 123 Stat. 1115 (2009). Thus, financial companies with outstanding TARP funds are required to submit executive pay to a shareholder vote under both TARP and Dodd-Frank. The SEC has made clear that only one vote, however, is necessary to satisfy both statutory requirements. See SEC Final Rule, 33-9178, Shareholder Approval of Executive Compensation and Golden Parachute Compensation 55, available at http://www.sec.gov/rules/final/2011/33-9178.pdf (vote under EESA is "effectively" the same as required by DoddFrank). Given that TARP recipients are required to conduct a "say on pay" vote annually, the SEC has exempted them from a vote on the frequency of "say on pay." Rule 14a-21(b); see Final Rule, at 57-58.

${ }^{141}$ See Shareholder Approval of Executive Compensation of TARP Recipients, Exchange Act Release No. 34-61335 (Jan. 12, 2010) [75 FR 2789] (adopting Rule 14a-20 to require TARP recipients to provide a separate non-binding shareholder vote to approve compensation of executives whenever shareholders vote at an annual meeting involving election of directors).

${ }^{142}$ Posting of Ted Allen to Risk \& Governance Blog, available at http://blog.issgovernance.com/gov/2009/02/tarpfirms-to-face-pay-votessubmitted-by-ted-allen-publications.html (Feb 23, 2009, 11:21 A.M.).

${ }^{143}$ Compensation Structure and Systemic Risk: Hearing Before the H. Comm. on Financial Services, 111 Cong. Serial No. 111-42 at 52-53. (June 11, 2009) (testimony of Professor Verret), available at http://www.gpo.gov/fdsys/pkg/CHRG-111hhrg52398/pdf/CHRG-111hhrg52398.pdf. In testimony before Congress during the hearings on Dodd-Frank, Professor Verret stated: 
season, shareholders at TARP-funded firms on average voted $88.7 \%$ in support of managementsponsored Say on Pay proposals. This is interesting given that most mandatory Say on Pay votes in 2010 were held at financial firms that had fared poorly during the financial crisis.

\section{B. Legislation and Implementation}

Section 951 of the Dodd-Frank Act requires public companies to give their shareholders an advisory vote to approve or disapprove the compensation paid to named executives during the prior fiscal year. ${ }^{144}$ The Act also requires an advisory vote by shareholders on golden parachute payments in any acquisition or merger. ${ }^{145}$ None of these votes, however, is to carry any mandatory force or change directors' duties to shareholders. ${ }^{146}$ New Section 14A of the Securities Exchange Act of 1934 requires that management present "a separate resolution subject to shareholder vote to approve the compensation of executives", though the vote "shall not be binding on the issuer or the board of directors." ${ }^{147}$

The SEC implemented Section 951 of Dodd-Frank with detailed requirements that specify the form of the Say on Pay proposal and the executive officers whose pay is subject to a shareholder vote. The SEC required Say on Pay votes at public companies with more than a $\$ 75$ million in public equity float beginning with shareholder meetings held after January $21,2011 .^{148}$

The Say on Pay vote applies only to the company's CEO and the four other executive officers named in the company's proxy compensation table. ${ }^{149}$ The vote relates to the compensation disclosed in the proxy statement as described in the Compensation Discussion and

The average vote was a $60 \%$ vote against say-on-pay by the shareholders. At financial companies it is even higher. $70 \%$ was the average vote against say-on-pay at financial companies. So shareholders have at least - shareholders at the majority of companies in a very strong majority way have expressed dissatisfaction with say-on-pay proposals.

${ }^{144}$ Dodd-Frank Wall Street Reform and Consumer Protection Act 2010.

${ }^{145}$ Exchange Act $\S 14 \mathrm{~A}(\mathrm{~b})$.

${ }^{146}$ Exchange Act $\S 14 \mathrm{~A}(\mathrm{c})(1),(\mathrm{c})(2)$.

${ }^{147}$ Exchange Act $\S 14 \mathrm{~A}$ (a) (1), (a) (2). In addition, affected companies must hold an advisory vote at least every six years on whether the say-on-pay vote will occur every one, two, or three years. Exchange Act $§ 14$ A (a) (2).

148 SEC Final Rule, 33-9178, Shareholder Approval of Executive Compensation and Golden Parachute Compensation 55, available at http://www.sec.gov/rules/final/2011/33-9178.pdf. Smaller reporting companies become subject to the say-on-pay voting requirement for annual meetings after January 21, 2013.

149 See Exchange Act Rule 14a-21(a) ("say on pay" vote required at annual shareholder meetings at which directors are elected for named executives whose compensation is disclosed pursuant to Item 402 of Regulation S-K). The compensation of directors is not subject to a mandatory "say on pay" vote. See SEC Final Rule, SEC Final Rule, 339178, Shareholder Approval of Executive Compensation and Golden Parachute Compensation 55, available at http://www.sec.gov/rules/final/2011/33-9178.pdf at 18. 
Analysis (CD\&A). ${ }^{150}$ The vote is up or down as to the overall compensation package, and not as to the specific elements of compensation (such as bonuses, stock options, retirement pay, performance incentives). ${ }^{151}$

The results of the Say on Pay vote must be disclosed on Form 8-K within four business days after the shareholders' meeting. ${ }^{152}$ In addition, the company must disclose -- in the next year's CD\&A -- whether and how the board considered the results of the shareholder Say on Pay vote in making any decisions. ${ }^{153}$

\section{Impact of Say on Pay}

In the 2011 proxy season, the inaugural year for Say on Pay, shareholders voted on these management proposals at about 2,200 US public companies. ${ }^{154}$ Briefly, the results showed several clear trends. First, shareholders strongly supported existing pay practices at most firms with Say on Pay votes garnering on average 91.2\% support. Second, these proposals were voted down only $1.6 \%$ of the time ${ }^{155}$ mostly based apparently on by pay-for-performance concerns. Third, shareholder votes were highly correlated to company share returns and CEO pay, with low returns and high CEO pay resulting in lower Say on Pay support. Fourth, negative Say on Pay recommendations by third party voting advisors, ISS and others, prompted many companies to modify their disclosure filings or to change their pay practices (sometimes retroactively) to win support.

\footnotetext{
${ }^{150}$ The SEC rule does not require that the management-submitted "say on pay" proposal be phrased in a particular way, though it must indicate that the proposal seeks a shareholder vote "to approve the compensation of executives as disclosed pursuant to Item 402 of Regulation S-K." Final Rule, supra note, at 19. A suggested proposal calls on shareholders to approve "compensation paid ... as disclosed pursuant to Item 402 of Regulation S-K, including the Compensation Discussion and Analysis, compensation tables and narrative discussion." Id.at 19 n.68. A vote to approve only compensation policies and procedures would not pass muster. Id at 19-20.

${ }^{151}$ See Exchange Act Rule 14a-21(a). In addition, the SEC added a comment to Rule 14a-8 that companies will be allowed to exclude shareholder-submitted proposals under the rule if the shareholder proposes a "say on pay" vote with "substantially the same scope the say-on-pay vote required by Rule 14a-21(a)."

152 See Item 5.07, Form 8-K. See also SEC Final Rule, 33-9178, Shareholder Approval of Executive Compensation and Golden Parachute Compensation 55, available at http://www.sec.gov/rules/final/2011/33-9178.pdf at 49 (changing disclosure on shareholder vote on "say on pay" frequency, but not shareholder votes on "say on pay" resolution).
}

153 SEC Final Rule, 33-9178, Shareholder Approval of Executive Compensation and Golden Parachute Compensation 55, available at http://www.sec.gov/rules/final/2011/33-9178.pdf at 23 (amending Item 402(b)(1) to disclose how company "considered the results of previous shareholder [say on pay] votes ... in determining compensation policies and decisions and, if so, how that consideration has affected its compensation policies and decisions." The disclosure is limited to the company's response to the most recent "say on pay" vote.

154 ISS, Preliminary 2011 U.S. Postseason Report, at 2. (updated August 8, 2011). Equilar, a leading provider of data on executive pay, counted 2,252 from the Russell 3000 as of June 30, 2011. Equilar, An Analysis of Voting Results and Performance at Russell 3000 Companies (July 2011), http://www.equilar.com/knowledgenetwork/research-articles/2011/pdf/Equilar-Voting-Analytics-July2011.pdf.

155 The Russell 3000, an index representing the 3000 largest US public companies by market capitalization and representing of $98 \%$ the public market, http://www.russell.com/indexes/data/fact_sheets/us/russell_3000_index.asp. 
The 2011 proxy season was claimed by some to be a watershed event in U.S. corporate governance. The Say on Pay votes mandated by Dodd-Frank, in these commentators' eyes, catalyzed greater management attention to shareholder concerns, increased shareholder interest in voting on corporate governance, and a broader dialogue on pay issues between management and shareholders (and proxy advisory firms). ${ }^{156}$

One thing that did not happen during the 2011 proxy season, however, was a shareholder backlash at increasing levels of executive pay. Despite some third party voting advisors' recommendations that Say on Pay proposals be evaluated, in part, on the basis of whether inappropriate "peer group benchmarking" had led to ratcheting up of executive pay, the upward spiral in CEO pay seemed not to be on the minds of shareholders.

Even before the Say on Pay vote, management at many companies made changes to the substance and disclosure of their pay programs. According to a study by the Conference Board on pay practices, many companies changed the terms of their pay programs to more clearly align pay to performance. In addition, many companies revised the content of the Compensation Discussion \& Analysis (CD\&A) filed with the annual meeting proxy materials. At many companies whose pay programs received negative Say on Pay recommendations by proxy advisory firms, management at some such companies engaged with shareholders following an "against" recommendation.

Management at many companies also seems to be responding more to Say on Pay rebukes. For example, two companies that voluntarily put Say on Pay on the ballot in 2010 (Occidental Petroleum and KeyCorp) and received majority opposition, changed their pay practices. ${ }^{157}$ As a result, shareholders gave significantly more support to the revised pay packages at these firms in 2011. Some companies with failed Say on Pay votes in 2011, however, have chosen not to change their pay practices, but instead to blame the proxy advisory firms.

\section{Empirical Research and Implications}

One empirical study of the 2011 Say on Pay voting results used multiple regression analysis to examine what factors influence the percentage shareholder vote in favor of Say on Pay. It looked at the following independent variables: (1) negative ISS recommendation, (2) excess CEO pay, (3) percentage change in CEO pay, and (4) an interaction term for companies that are both in the highest quintile for excess pay and the lowest quintile for total stock return (that is, the worst performing companies with the most excessively-paid CEOs). The study found that all of these independent variables are negative factors in Say on Pay votes and statistically significant, except for percentage change in CEO pay -- which was insignificant. However, an ISS "against" recommendation is much more relevant to shareholder voting than - and even dwarfs in predictive value -- the "excess" pay and combined low TSR/high excess pay. ${ }^{158}$ This

\footnotetext{
${ }^{156}$ Luis A. Aguilar, Comm'r, U.S. Sec. \& Exch. Comm'n, Speech to Social Investment Forum (June 10, 2011).

${ }^{157}$ At Occidental the company cut CEO long-term incentive opportunities by $70 \%$, expanded peer benchmarks, and reduced award opportunities for other executives.

${ }^{158}$ A second study makes similar findings. Yonca Ertimur, Fabrizio Ferri and David Oesch, "Shareholder Votes and Proxy Advisors: Evidence from Say on Pay" March 11, 2012, available at:
} 
analysis suggests that the ISS may be identifying the principal factors that shareholders find relevant in their Say on Pay votes -- or that shareholders believe the ISS has done this for them.

The analysis also suggests that shareholders on their own - though to a lesser extent than the ISS - identify some "outlier" companies based on their independent analysis of "excess" pay and its interaction with TSR. In all, the ISS identification of "outlier" companies through an "against" voting recommendation and the further identification of such companies by shareholders (beyond that contained in a negative ISS recommendation) based on company "excess" pay/TSR seem to explain how Say on Pay was used in its inaugural year to identify and discipline pay practices at "outlier" firms. Nonetheless, these factors were less than fully explanatory of Say on Pay voting in the first year under Dodd-Frank and other factors may have been influential.

Several other papers have recently examined different aspects of Say on Pay in the U.S. One important study found that the stocks of firms with excessively high executive remuneration reacted positively to the passage of the federal legislation enacting Say on Pay, indicating that shareholders of these firms viewed this event as positive news. ${ }^{159}$ Another paper casts doubt on the value of companies revising their pay packages in response to negative Say on Pay votes, finding that companies that did so experienced stock price drops. ${ }^{160}$

The first year of Say on Pay under Dodd-Frank confirmed that executive pay is on the minds of shareholders in U.S. companies. Led by the ISS, shareholders showed their concern though not reflexively -- about pay packages that rewarded CEOs despite weak company stock performance or with excess pay compared to that at similar companies. More than any factor, though, being targeted by the ISS for "outlier" pay practices was relevant to shareholder Say on Pay voting. However, excess compensation levels and poor corporate performance are also important triggers for negative stockholder votes. Say on Pay votes increase the pressure on companies to tie pay to performance. ${ }^{161}$

Changes in corporate governance behavior - such as more complete disclosure of payfor-performance policies and the reversal of specific, controversial pay practices -- inaugurated by Say on Pay in 2011 appear to be continuing apace and maybe even gathering strength in 2012. ${ }^{162}$ It appears that in the U.S. shareholder scrutiny of corporate pay practices using Say on Pay votes will not be a passing phenomenon.

IV. Should New Zealand Adopt Say on Pay?

http://papers.ssrn.com/sol3/papers.cfm?abstract_id=2019239. This paper also documents a significant negative stock price reaction to the release of a negative ISS voting recommendation.

${ }^{159}$ Jie Cai \& Ralph A. Walkling, “Shareholders' Say on Pay: Does it Create Value” February 2008, available at: http://ssrn.com/abstract=1101881.

${ }^{160}$ David F. Larcker, Allan L. McCall and Gaiska Ormazabel, "The Economic Consequences of Proxy Advisor Sayon-Pay Voting Policies" July 5, 2012, available at: http://ssrn.com/abstract=2101453.

${ }^{161}$ Che Odom, "Say-On-Pay Votes May Have Caused Shift in CEO Compensation, Expert Says" Corporate Law Daily, BNA, July 25, 2012.

${ }^{162}$ Vipal Monga and Emily Chasan, “Companies Come Courting” Wall St. J., August 21, 2012 at B5. 


\section{A. Lessons to Draw From Elsewhere}

What lessons should New Zealand draw from other countries' experiences with Say on Pay? Academics predicted that Say on Pay would alter the shareholder role in corporate governance, differing on whether this was a good or a bad thing. In fact, Say on Pay has made relatively little difference to the existing allocation of power in the U.K. and U.S. to present. Other academics questioned whether shareholders are competent to evaluate executive pay, an argument bolstered by the high level of voting support on Say on Pay proposals to date. However, there is evidence that shareholders vote against proposals at firms with abnormally high levels of executive pay that are experiencing poor corporate performance. Reports from the U.K., where Say on Pay has been in place since 2002, indicate that it has had a positive effect on corporate governance and increased sensitivity to "excess" CEO pay in poorly performing firms. ${ }^{163}$

There are also two features of the New Zealand corporate governance system that may make Say on Pay less effective from shareholders' perspective. First, there are relatively few public companies that have dispersed ownership structures. In other words, at most New Zealand public companies shareholders already have substantial power to influence executive pay by virtue of their relative high concentration or blockholdings. Second, presently there are no third party voting advisors based in New Zealand. Given the lack of barriers to entry for these firms, their absence likely reflects a lack of demand for their services currently. Taking into account the relatively small number of dispersed ownership firms in New Zealand, it seems unlikely that implementing Say on Pay will change that situation.

This mitigates the concern, expressed in the U.S. and U.K., that Say on Pay increased the power of proxy voting advisory firms. Proxy advisory firms can serve a useful function, including acting as monitors for shareholders. The evidence of their value to shareholders in Say on Pay votes is somewhat mixed though.

Critics predicted that Say on Pay would not halt spiraling executive pay and that has largely proved to be correct. In the U.S., where Say on Pay has been in place only since 2011, Say on Pay proposals were only voted down $1.6 \%$ of the time, ${ }^{164}$ mostly based on pay-for-performance concerns. ${ }^{165}$ There was no apparent shareholder backlash at escalating executive pay. ${ }^{166}$

\footnotetext{
${ }^{163}$ See Yonca Ertimur, Fabrizio Ferri \& Volkan Muslu, "Shareholder Activism and CEO Pay”(2011) 24 Rev. Fin. Stud. 535, at p576.

${ }^{164}$ Randall S. Thomas, Alan R. Palmiter and James F. Cotter, "Dodd-Frank's Say on Pay: Will It Lead to a Greater Role for Shareholders in Corporate Governance?"(2012) 97 Cornell L. Rev. 1213, at pp 1248-49. The 3,000 largest U.S. public companies by market capitalization comprise $98 \%$ of the U.S. public equity market and are represented on the Russel 3000. Russell 3000 Index, Russell, http:// www.russell.com/indexes/data/fact_sheets/us/russell_3000_index.asp (last updated Mar. 31, 2012).

${ }^{165}$ Ibid, at p 1249; see also ISS Preliminary Report, Item 5.07, Form 8-K, at 1.

${ }^{166}$ Ibid, at p 1257.
} 
Predictions by some that Say on Pay would strengthen the pay-for-performance relationship have had mixed reviews. While at most companies, shareholders have been willing to accept board's views on the subject, there is evidence of fewer "rewards for failure" at UK firms after implementation of Say on Pay there. ${ }^{167}$ Most interestingly, negative say on pay recommendations by proxy firms resulted in many companies changing their pay practices to win support with one study showing these negative recommendations have more effect on voting than any other factor. ${ }^{168}$ Like the U.K., changes in corporate governance behavior also seemed to be emerging.

\section{B. Can Say on Pay Be Adopted With Existing New Zealand Corporate Law?}

Do New Zealand's existing corporate code and practices create any barriers to the adoption of an advisory Say on Pay vote? One anachronistic practice in New Zealand listed companies that potentially limits the ability of institutional shareholders to restrict excessive executive director remuneration is the continuation of the practice of voting by show of hands. The New Zealand Stock Exchange requires listed companies to include a section on voting at shareholder meetings in their constitution but many companies adopt rules around meetings that are similar to those found in the First Schedule of the Companies Act 1993. The chairperson is empowered to determine the method of voting unless a poll is demanded. The chairperson can choose either voting by voice or by show of hands. A declaration by the chairperson that the resolution is carried is conclusive unless a poll is then demanded. ${ }^{169}$ This practice would have to be discontinued if New Zealand decided to implement Say on Pay legislation. Say on pay is predicated on one vote per share and, as overseas experience shows, proxy voting and ideally the development of proxy advisory firms should become prevalent for say on pay legislation to be effective. The tradeoff would be the introduction of a more bureaucratic and time consuming voting system in meetings with resulting and associated delays and costs. However, even if say on pay were not adopted, fostering the development of proxy advisory firms and encouraging proxy voting may benefit the New Zealand share market.

If desired, there are at least two existing corporate law rules and practices that could be modified to adopt advisory Say on Pay in New Zealand. First, the New Zealand Companies Act 1993 has a little utilized provision that potentially would allow shareholders to have Say on Pay. Section 109 mandates that the chairperson of a meeting of shareholders of a company must allow a reasonable opportunity for shareholders at the meeting to question, discuss, or comment on the management of the company. A meeting of shareholders may pass a resolution under this section

\footnotetext{
${ }^{167}$ Fabrizio Ferri \& David Maber, Say on Pay Votes and CEO Compensation: Evidence from the U.K., Review of Finance 1 (2013).

${ }^{168}$ Lynn A. Stout, Why Should ISS Be the New Master of the Corporate Governance Universe?, Corp. Governance, Jan. 4, 2006, at pp 14-15. For example, Professor Stout has indicated that "[w]hen institutional investors follow ISS [vote recommendations] en masse, directors of public corporations can expect to see $20 \%, 30 \%$ even $50 \%$ of their company's shares being voted not as the directors recommend, but as ISS recommends."

${ }^{169}$ Companies Act 1993, First Schedule, clause 5(3).
} 
relating to the management of a company. Unless the constitution provides that the resolution is binding, such a resolution is not binding on the board.

A second alternative method would be for shareholders to ask for a poll. Under current law, five shareholders, or a shareholder or shareholders holding $10 \%$ of the voting power or the paid up capital in the company, can demand a poll. ${ }^{170}$ Also, if a chairperson holds sufficient postal votes to make him or her believe it may change the outcome of the vote, the chairperson must call for a poll. $^{171}$ A poll may be demanded either before or after the vote is taken on a resolution but it is relatively unusual for this right to be exercised at the annual meeting. Some commentators have called on shareholders to exercise this right. ${ }^{172}$

A third option would be to simply adopt the U.K. rule, or the American rule, suitably modified to conform to the requirements of New Zealand corporate law. Section 211 of the Companies Act 1993 could be amended to extend the requirement that each director's remuneration be disclosed to a requirement that a directors' report be prepared that contains details of board policy on remuneration and the relationship between pay and performance. To be consistent with other jurisdictions, the requirement could be limited to listed companies. Such a requirement exists in Australia, although Australia, with its two strikes regime, goes further. ${ }^{173}$ Section 161 could be amended to require a non-binding ordinary resolution approving the directors' remuneration report. Alternatively s 109 could be amended extending shareholders' right to vote on the management of the company to a right to vote on the directors' remuneration report.

\section{Should New Zealand Adopt Say on Pay?}

At the end of the day, in our view, the arguments for introducing Say on Pay are not compelling either for it or against it. There is no evidence that it would drive down the level of executive remuneration levels in New Zealand. Rather, as in other jurisdictions, current CEO pay levels and increases seem to be more a result of existing disclosure regimes and labor market forces than a lack of shareholder power. Evidence from the U.K. and U.S. does indicate that say on pay votes there have had an effect on pay-for-poor-performance. However, it is unclear that

\footnotetext{
${ }^{170}$ Ibid, clause 5(4), First Schedule.

${ }^{171}$ Ibid, clause 7(7), First Schedule.

172 B Gaynor, "Shareholders should demand poll votes" The New Zealand Herald, 4 August, 2012 ("New Zealand shareholders should be demanding poll votes, particularly on contentious issues and on all special resolutions where a 75 per cent majority is required.")

${ }^{173}$ See Regan Adamson \& Daniel Lumm, Shareholder Democracy and the Say on Pay Movement: Progress, But How Do You Define Success? 6 (Working Paper, Wake Forest L. Rev.), available at http://lawreview.law.wfu.edu/files/2011/02/working.2009.adamson.lumm_.pdf. The Corporations Amendment (Improving Accountability on Director and Executive Remuneration) Act 2011, in sections 250R(2), 250U$\mathrm{V}$, mandates that if at two consecutive meetings over $25 \%$ of shareholders vote against the directors' remuneration package, at the second AGM the shareholders will have to vote on a spill motion. If the spill motion receives approval by a simple majority, the directors have to stand for election again within 90 days. This is known as the "two strikes" regime.
} 
those countries' experience will extend to New Zealand as shareholders in those nations rely heavily on the recommendations of ISS to overcome significant collective action problems. At present, in New Zealand, no comparable third party voting advisor firms exist.

The strongest arguments in favor of Say On Pay's introduction are the likelihood it will have some effect of remuneration of executives in poorly performing firms, and that it may lead to a possible improvement in the standard of corporate governance driven by the increased shareholder scrutiny of pay packages that would be part of such a reform. It is likely to lead to greater dialogue between shareholders and directors about executive remuneration, but the empirical evidence from the U.S. is that too much responsiveness by corporate directors on pay changes is viewed negatively by the stock market. ${ }^{174}$ Finally, the desirability of harmonizing New Zealand's laws with those in comparable jurisdictions, in particular the U.K. and Australia, where Say on Pay has been in place for many years, is a valid, but not decisive, argument in support of its introduction. It is worth noting that both of those countries have abandoned the non-binding shareholder vote on executive remuneration in favor of a binding vote, and that the impact of that change is yet to be determined.

\footnotetext{
${ }^{174}$ David F. Larcker, Allan L. McCall and Gaiska Ormazabel, "The Economic Consequences of Proxy Advisor Sayon-Pay Voting Policies” July 5, 2012, available at: http://ssrn.com/abstract=2101453.
} 